Bogusław Paź

Uniwersytet Wrocławski, Wrocław

ORCID: 0000-0002-4667-8509

e-mail: boguslaw.paz@uwr.edu.pl

\title{
Monadologia neurologica Wykładnia monadologicznej teorii świadomości według Olivera Sacksa
}

\section{Wstęp}

Monadologiczna metafizyka Gottfrieda Wilhelma Leibniza od samego początku nie znajdowała zrozumienia u jego współczesnych. Praktycznie do dnia dzisiejszego trudno mówić o powszechnej znajomości i rozumieniu jej podstaw wśród humanistów. Według powszechnej opinii Leibnizjańska metafizyka i wizja człowieka jako monady są całkowicie abstrakcyjne i przeczą podstawowym danym doświadczenia ${ }^{1}$. Reprezentatywny jest pogląd Immanuela Kanta, który opatrzył ją mianem "najdziwniejszego wymysłu” (das wunderlichste Figment) w dziejach filozofii. Dwie najważniejsze próby całościowego wykładu monadycznej wizji człowieka dokonane przez Leibniza, czyli jego opus magnum Les Nouveaux Essais sur l'entendement humain $(1704)^{2}$ oraz La Monadologie (1714), pomimo klarownego i systematycznego charakteru utrwaliły ten pogląd. Szczególnie ważny w tym względzie był słynny § 7 Monadologii,

${ }^{1}$ Jedna z typowych współczesnych opinii o filozofii Leibniza: „,jeden z najbardziej nieoczywistych i niezrozumiałych systemów w dziejach filozofii". Wojciech Chudy, Rozwój filozofowania a "pułapka refleksji”. Filozofia refleksji i próby jej przezwyciężania (Lublin: RW KUL, 1995), 161.

${ }^{2}$ Korzystam z przekładu: Gottfried Wilhelm Leibniz, Nowe rozważania dotyczace natury umystu ludzkiego, przeł. Izydora Dąmbska (Kęty: Antyk, 2001) (cyt. NR). 
w którym czytamy, że „Monady nie mają okien, przez które cokolwiek mogłoby się dostać czy też $\mathrm{z}$ nich wydostać" ${ }^{3}$. Odczytano go w duchu skrajnego epistemologicznego reprezentacjonizmu, izolacjonizmu i solipsyzmu, które radykalnie odbiegały od naturalnego doświadczenia i zdroworozsądkowych przekonań.

Leibnizjańskie koncepcje w obszarze logiki (calculus ratiocinator), teorii języka (characteristica universalis) czy ontologii, np. teoria światów możliwych, zyskały pełne zrozumienie i stały się inspiracją dla licznych współczesnych myślicieli. U nich też znajdowały one swoje twórcze rozwinięcie. Nie dotyczyło to jednak jego antropologii, psychologii i epistemologii. Było tak, pomimo że Leibniz wypracował odkrywcze i efektywne poznawczo różnorakie koncepcje, które rozwiązywały aporie filozofii Kartezjusza: po pierwsze mocną, odwołującą się do naturalnego doświadczenia koncepcję tzw. moralnej i realnej tożsamości podmiotu, która ma praktyczne zastosowanie w obszarze antropologii i prawa; po drugie bardzo efektywna pod względem poznawczym okazała się jego zasada ciągłości (principium continuationis) głosząca ciągłość i gradację procesów, zjawisk i stopni bytowej doskonałości, mająca zastosowanie nie tylko w metafizyce, ale i w psychologii; po trzecie Leibniz był krytykiem filozofii Kartezjusza, zwłaszcza jego dualizmu w obszarze antropologii oraz fizykalizmu i mechanicyzmu redukującego to, co cielesne w człowieku, do elementów ilościowych, opisywalnych w języku matematyki i mechaniki („,Apud me omnia fiunt mathematice in Natura") $)^{4}$. Szczególnie ważne w tej Leibniza krytyce kartezjanizmu było podkreślanie osobowego charakteru człowieka, który nie tyle był „rzeczą myślącą" (res cogitans) lub „czymś myślącym”, ale przede wszystkim osoba, czyli pewnym kimś: „Duch tutaj nie jest rozumiany jako rzecz myśląca (jak zwykle bywa gdzie indziej), lecz jako dusza lub forma do duszy analogiczna, nie jako prosta modyfikacja, lecz jako coś konstytutywnego, substancjalnego i trwałego, co mam zwyczaj określać mianem monady, w której jest jakby percepcja i dążenie (appettitus)" ${ }^{\prime 5}$. Te i inne osiągnięcia myśli Leibniza nie znalazły swojej kontynuacji - z nielicznymi wyjątkami - we współczesnej myśli filozoficznej. Co jest powodem

${ }^{3}$ Korzystam z przekładu Stanisława Cichowicza Zasady filozofii, czyli monadologia (cyt. Mon.) § 7, w: Gottlieb Wilhelm Leibniz, Zasady filozofii, czyli monadologia, § 33, przeł. Stanisław Cichowicz, w: Gottlieb Wilhelm Leibniz, Wyznanie wiary filozofa. Rozprawa Metafizyczna. Monadologia. Zasady natury i łaski oraz inne pisma filozoficzne, przeł. Stanisław Cichowicz i in., oprac. Stanisław Cichowicz (Warszawa: PWN, 1969) (cyt. WWF).

4 René Descartes, Oeuvres de Descartes, publiées par Charles Adam et Paul Tannery (Paris: Leopold Carf, 1897-1913), t. 3, 36.

${ }^{5}$ Gottfried Wilhelm Leibniz, „O naturze samej”, przeł. Krystyna KrauzeBłachowicz, w: Gottlieb Wilhelm Leibniz, Pisma z metafizyki natury, red. Seweryn Blandzi (Toruń: Wydawnictwo Rolewski, 1999), 61. 
takiego stanu rzeczy? Jak się zdaje, jego poszczególne tezy metafizyczne brzmią niezwykle abstrakcyjnie, a niektóre z nich wręcz wydają się sprzeczne z naszym codziennym doświadczeniem. Tak więc zasadnicze trudności w recepcji metafizyki Leibniza można sprowadzić do problemu trudności w znalezieniu określonego języka i empirycznego obrazu lub modelu, który unaoczniłby zasadnicze elementy tej metafizyki, czyli jak określiłby Arystoteles: „postawił je przed oczami” ( $\pi$ ò ö $\mu \alpha \tau \tau o ~ \pi o \imath \varepsilon \hat{v}$; Rhetorica, 1411b 25) czytelnika.

Taki stan trwał do 1973 roku, kiedy to brytyjsko-amerykański psychiatra i neurolog Oliver Sacks opublikował pracę Awakeningss ${ }^{6}$, w której opisał stany kilku swoich pacjentów cierpiących na różne postaci encefalopatii. Wśród podanych przez niego opisów i analiz związki z monadyczną koncepcją świadomości najwyraźniej widać na przykładzie pacjenta o imieniu Leonard. Twierdzę, że jego niezwykle poruszający przypadek w Mont Carmel Hospital, który został opisany przez Sacksa, w sposób bezpośredni ilustruje główne tezy autora Monadologii. Znajdujemy tam podstawy Leibnizjańskiej teorii świadomości, w szczególności koncepcję tożsamości realnej i moralnej, ale także zasadę kontinuum w obszarze różnych faz i form świadomości.

Zanim jednak przejdę do przedstawienia tego przypadku i ustaleń Sacksa, pragnę skrótowo przedstawić główne elementy Leibnizjańskiej metafizyki i teorii świadomości, których empiryczną obecność odnajdujemy w Sacksa opisach przebiegu choroby Leonarda.

\section{Dwa języki opisu}

Głównym problemem w recepcji filozofii Leibniza był zawsze abstrakcyjny język. Brało się to stąd, że prezentował on kolejne tezy systemu,

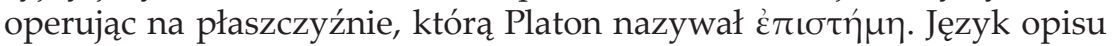
tego obszaru pozbawiony jest jakichkolwiek odniesień do świata fizycznego, w szczególności do sfery zmysłowej i cielesnej, którą określał jako

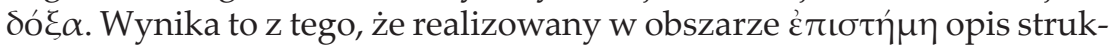
tury monadycznej świata obejmuje to, co ogólne, niezmienne i konieczne, a treści zmysłowe są zawsze jednostkowe, zmienne i niekonieczne. Na stronach swoich pism Leibniz - podobnie jak Platon - operował dwoma językami opisu, z których pierwszy odwoływał się do danych zmysłów lub wyobraźni (metaforyka), a drugi do treści czysto intelektualnych, rozumowych. Dane pierwszego języka były czymś konkretnym, ale zmiennym i przygodnym. Leibniz, pomimo przyjęcia skrajnego na-

${ }^{6}$ Korzystam z wydania Oliver Sacks, Awakenings (New York: Vintage Books, 1999) (cyt. A) oraz przekładu Oliver Sacks, Przebudzenia, tłum. Piotr Jaśkowski (Warszawa: Zysk i S-ka, 2011²) (cyt. P). 
tywizmu, uważał, że nasze poznanie zaczyna się - w porządku genezy od poznania zmysłowego (doświadczenia). Według niego punktem wyjścia naszego poznania jest naturalny, spostrzegany w naszej umyśle ś wi at, spontanicznie wyrażany w naturalnym języku, a punkt dojścia stanowi język i abstrakcyjny obraz ${ }^{8}$ monadycznego świata, jaki prezentuje oparta wyłącznie na refleksji metafizyka. To ostatnie ma charakter czysto intelektualny $\mathrm{w}$ sensie czysto intelektualnej intuicji (intellectio pura), o której pisał Kartezjusz w VI Medytacji. To pewien idealny sens, który jest odkrywany w aktach refleksji (Mon. § 29, 30). Ponieważ sens ten dany jest $\mathrm{w}$ aktach tak pojętej intuicji, jak to ujmował Plotyn, jest on

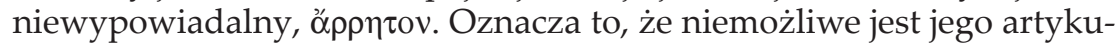
łowanie i komunikowanie w języku naturalnym, bazującym na danych zmysłowych. Dlatego też koniecznym wyrazem poznania metafizycznego jest metafora, która odwołuje się do znanego nam wszystkim obrazu świata fizycznego".

Właśnie w kontekście języka opisu ujawnia się znaczenie wspomnianej pracy Sacksa. Polega ono na tym, że według Leibniza w naszym poznaniu monadycznej struktury świata skazani jesteśmy albo na poznanie pośrednie i język naturalny, ale zarazem powiązany z metaforyka, albo na poznanie bezpośrednie, ale niedające się zobiektywizować i językowo w sposób zrozumiały dla odbiorcy wyartykułować ze względu na swoją abstrakcyjność. Sacks, wskazując na empiryczny przykład swojego pacjenta i opisując jego stan, a także posługując się jego własną relacją z przebiegu choroby, sprawił, że monadologiczne tezy uzyskały zarówno walor spostrzeżeniowej (zmysłowej) naoczności, jak i bezpośredniości, obiektywności i intersubiektywności.

\section{Zarys monadycznej psychologii}

Zanim jednak przedstawię Sacksa obserwacje psychiatryczno-neurologiczne i ich wyjaśnienia odwołujące się do monadologicznej psychologii świadomości, pragnę skrótowo przedstawić zarys Leibnizjańskiej monadologicznej koncepcji świadomości.

7 A następnie, dzięki apercepcji i refleksji, znajduje swoje rozwinięcie i zwieńczenie w postaci poznania czysto intelektualnego, którego przedmiotem są uzyskane na bazie refleksji idee i pojęcia.

8 Por. opozycję percepcja świata i życie-w-świecie versus życie-w-obrazie świata w pracy Martin Heideggera „Die Zeit des Weltbildes” (1938), w: Martin Heidegger, Holzwege (Frankfurt a. Main: Vittorio Klostermann, 2003), 5-113, zwł. 90-91.

9 Por. Cristina Marras, "The Role of Metaphor in Leibniz's Epistemology", w: Leibniz: What Kind of Rationalist?, red. Marcelo Dascal (New York: Springer, 2008), 199-212. 


\section{Zasada intencjonalności}

Zaprezentowany przez Leibniza w Monadologii obraz, jak również model monadycznej świadomości, posiada silne realistyczne ${ }^{10}$, metafizyczne presupozycje: metafizyczny pluralizm i realizm, dynamizm, indywidualizm itd. Praktycznie wszystkie tezy Leibnizjańskiej monodologii, $\mathrm{z}$ wyjątkiem jednej, tj. mówiącej o zamknięciu monad w nich samych, wskazują na naturalny obraz świata, który poprzedza Kartezjuszowe metodyczne wątpienie (dubito). Leibniz odrzucił bowiem Kartezjusza formułę cogito ergo sum na rzecz tej interpretacji, która na bazie aktu cogito wnosiła nie o istnieniu podmiotu (cogitans), ale o istnieniu pluralistycznego świata: „Ego cogito, et: Varia a me cogitantur"11. Przesłanką przyjęta implicite $\mathrm{w}$ tym rozumowaniu jest zasada intencjonalności, głosząca, że wszelkie myślenie jest myśleniem czegoś, co jest czymś różnym i obcym względem aktu myślenia. Innymi słowy, intencjonalność świadomości człowieka to określona struktura umysłu, która pierwotnie ukierunkowuje nas do czegoś innego (in aliud tendere) niż my sami, tj. zwraca nas w stronę świata. Zasada ta wyraża poznawczy i genetyczny prymat zorientowanej na świat intencji w stosunku do refleksji, która skierowana jest nie na poznawaną rzecz, ale na podmiot. W czasach Leibniza tak to wyrażał Antoine Arnauld: „Dlatego odkąd jest jasne, że ja myślę, to także jest jasnym, że ja myślę o czymś, [...] jest niemożliwym, aby myśleć, nie myśląc o czymś" "12. Intencjonalność na mocy wrodzonej nam struktury umysłu ukierunkowuje nas na świat i „zakotwicza” nas $\mathrm{w}$ nim. W przypadku aktów percepcji intencjonalność prowadzi do epistemologicznej asercji (łac. assensio, niem. Seinssetzung) i jest ona podstawą poznawczego realizmu. Na tle spontanicznej percepcji apercepcja i refleksja są genetycznie wtórne. Pod względem strukturalnym obie są nadbudowane na spontanicznie, tj. intencjonalnie (na zewnątrz), ukierunkowanej percepcji. $Z$ tego powodu nasze poznanie rozpoczyna

10 Zob. Bogusław Paź, „Cogito i intencjonalność. Realistyczny wymiar epistemologii i monadologicznej metafizyki Leibniza", Przeglad Filozoficzny. Nowa Seria 25, 4 (2016): 69-92; „Cogito und Intentionalität. Leibniz' Umdeutung des Grundprinzips von Descartes", w: Für unser Glück oder das Glück anderer, red. Wenchao Li i in., Band IV, Vorträge des X. Internationalen Leibniz-Kongresses Hannover, 18.-23. Juli 2016 (Hildesheim: Olms Verlag, 2016), 101-111.

11 Zob. Gottfried Wilhelm Leibniz, Die philosophischen Schriften von Gottfried Wilhelm Leibniz, red. C. I. Gerhardt, Berlin 1875-1890 (reprint Hildesheim: Olms Verlag, 1978) (cyt. GP), Bd. IV, 350-392, zwł. 357.

12 Korzystam z przekładu Antoine Arnauld, On True and False Ideas. New Objections to Descartes Replies, translated, with introduction by Ellmar J. Kramer (New York: The Edwin Mellen Press, 1990), 6 oraz najnowszego wydania oryginału: Antoine Arnauld, De Vraise et des fausses idées, edition, presentation et notes par Daniel Moreau (Paris: Libraire Philosophique J. Vrin, 2011), 52. 
się od percepcji i wraz z nią rozwija się niemająca swojego przedmiotu apercepcja. Cały zaś proces rozwoju naszego poznania zamyka refleksja (in actu signato), która ukierunkowana jest na podmiot, jego akty poznawcze i ich zawartość („,[...] refleksja nie jest niczym innym, jak tylko uwagą zwróconą na to, co nosimy w sobie..." NR, 22).

\section{Izolacjonizm}

Problem, który nasuwa się przy okazji rozważań wokół intencjonalności naszej świadomości i epistemologicznego realizmu, dotyczy słynnego stwierdzenia Leibniza o Monadologii, które można by nazwać zasadą izolacjonizmu: monady „nie posiadają »okien«, przez które cokolwiek mogłoby się do nich dostać lub z nich wydostać" (§ 7). Jak się okazuje, twierdzenie to tylko pozornie przeczy zasadzie intencjonalności i pierwotnemu otwarciu podmiotu na świat jako potencjalny obiekt naszej intencjonalności. Pomimo istotnych różnic Leibniz przyjmuje zasadniczy ontologiczny rys ludzkiego umysłu, jaki podał Arystoteles w De anima.

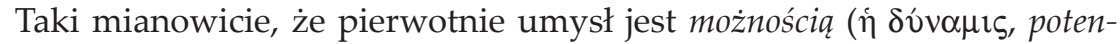
tia), która urzeczywistnia się, gdy bezpośrednio styka się poznawczo z tym, co jest w akcie ( mi i światem. Proces poznania jako proces właśnie ma podstawę w tym, co jest $\mathrm{w}$ akcie, co zostało nazywane entelechią przez Arystotelesa ( $\dot{\xi} \xi \dot{\varepsilon} v \tau \varepsilon \lambda \varepsilon \chi \varepsilon \dot{\alpha} \alpha$, De anima, 431a 3-4) i Leibniza (Mon. § 18).

Opisane w $\S 7$ Monadologii monady to podmioty o całkowicie rozwiniętym (zaktualizowanym) umyśle. Umysł taki - w pewnej analogii do opisu Boga w ks. $\Lambda$ Metafizyki Arystotelesa - jest podmiotem, który osiągnął poznawczą samowystarczalność (Leibniz na jej oznaczenie uży-

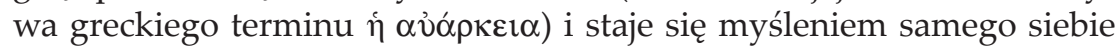

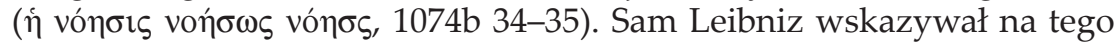
rodzaju samo-wystarczalność w § 18 Monadologii: „właściwa im samowystarczalność ( wewnętrznych i - rzec można - bezcielesne automaty". Umysł, który osiągnął taką fazę rozwoju, sam dla siebie jest przedmiotem i zarazem podmiotem poznania. Samo zaś poznanie oznacza wydobywanie na jaw (łac. recludere) tego, co pierwotnie jest w nim skryte, choć od zawsze obecne. To tłumaczy sens przesłanki o wrodzoności wiedzy, która w swojej zawartości reprezentuje świat zewnętrzny. Za sprawą tej wrodzoności monada jest definiowana jako „żyjące zwierciadło” ${ }^{13}$, które spoglądając

${ }_{13}$ Leibniz, Mon. § 62, 63, 77; Rozprawa metafizyczna, pkt. 9, 35, w: WWF, 106-107, 142-143; Zasady natury i łaski oparte na rozumie, § 12, w: WWF, 290-291. 
$\mathrm{w}$ siebie $\mathrm{w}$ aktach refleksji, widzi to, co jest poza nią ${ }^{14}$. Ponadto staje się jasne, dlaczego monady nie potrzebują już żadnych „okien”, które symbolizują percepcję zewnętrzną, aby poznać świat zewnętrzny. Monada, która jest bytem czysto duchowym, nie poznaje świata $\mathrm{w}$ aktach percepcji zmysłowej intencjonalnie ukierunkowanej na zewnętrzny świat. Czyni to w refleksyjnych aktach samopoznania, w których niejako zagłębia się sama w sobie i zarazem w tym, co sobie, tj. na powierzchni lustra, $\mathrm{w}$ postaci mentalnych reprezentacji odnajduje jako transcendentny świat poza nią.

\section{3. Świadomość i język w monadologicznej filozofii}

Jeśli więc poznanie $\mathrm{w}$ sensie ścisłym jest realizowane na bazie refleksji, to jaki jest epistemologiczny status percepcji zmysłowej i towarzyszącej jej apercepcji? Jeśli chodzi o percepcję zmysłową i apercepcję, to nie są one realnym źródłem poznania. Ich funkcja sprowadza się do budzenia ${ }^{15}$ (fr. réveiller) umysłu. Pisze o tym wprost Leibniz w "Przedmowie" do Nowych rozważań: „[...] dusza z natury zawiera podstawy pewnych pojęć i teorii, a przedmioty zewnętrzne tylko je rozbudzaja [reveillient] w odpowiednich warunkach" (NE 18; podkr. i uzup. B.P.). Wśród czynników budzących refleksję, czyli poznanie w sensie ścisłym, oprócz zmysłowej percepcji i apercepcji należy wymienić jeszcze niepokój (fr. inquiétude), czyli stan, w którym człowiek odkrywa „brak jakiejś rzeczy, która, gdyby była obecna, sprawiłaby mu przyjemność [...]. Niepokój jest głównym, aby nie powiedzieć jedynym, bodźcem, który stymuluje przemyślność i aktywność człowieka” (NE, II, XX, § 6). W tym stanie „małe niedostrzegalne pobudzenia trzymają nas zawsze w napięciu" (NE, II, XX, § 6). Niepokój (inquiétude) jest formą tego, co przez Leibniza gdzie indziej jest ujmowane jako „świadomość lub refleksja towarzysząca wewnętrznemu działaniu" (NE, II, XXVII, § 13). To jest świadomość jego braku, która zawsze jest niewyraźna i negatywna. Ponadto - podobnie jak apercepcja - nie posiada ona przedmiotu w sensie ścisłym. To różni ją od zmysłowej percepcji, która jest percepcją poszczególnych fizycznych rzeczy, oraz od refleksji, której korelatem są różne formy reprezentacji (obrazy, idee, znaki).

Wspomniany stan niepokoju organizuje nasze pole poznawcze w postaci jego centrum i horyzontu (tła). Centrum to punkt, na który ukierunkowana jest nasza uwaga, a dokładniej: poznawcza intencja (intentio, acies mentis) jako cecha naszych zmysłów i umysłu, która ukierunkowuje je na określone obiekty. Wraz z wyłonieniem się w naszej

14 Bycie poza świadomością monady posiada cechy „transcendencji w immanencji" (die Immanenz in der Transzendenz), o której pisał Edmund Husserl.

15 Zob. Leibniz, Mon. § 23. 
świadomości owego centrum równocześnie tworzy się swoisty horyzont (tło) tego pola, tj. potencjalna sfera, na którą może zostać przekierowana nasza uwaga $\mathrm{z}$ jednego obiektu na inny ${ }^{16}$. Tę potencjalną sferę wyznacza obszar tego, co hanowerczyk nazywał petite perceptions, niewielkie spostrzeżenia, które nie zostały poddane refleksji ${ }^{17}$.

Aby następował rozwój poznania i świadomości, żadna monada w swoim rozwoju na początku nie może się obyć ani bez ukierunkowanej intencjonalnie percepcji zmysłowej i towarzyszącej jej apercepcji, ani wspomnianego stanu niepokoju, gdyż genetycznie inicjują one początek aktów refleksji jako właściwego źródła poznania.

\section{Mowa i język}

Również zgoła inna od Arystotelesa i powszechnie przyjmowanej w nurcie scholastyki była Leibniza koncepcja języka, a dokładniej mowy. Nawiązywał do natywistycznej wykładni języka Augustyna z Hippony, zwłaszcza jego nauki o słowie umysłu (verbum mentis) i mowie serca (lingua cordis). Różnica pomiędzy obu ujęciami polegała na tym, że w ujęciu arystotelików geneza języka rozpoczyna się wraz ze zmysłową percepcją, a sam język jest reprezentacją poznawanych struktur świata. Według Augustyna i Leibniza język jest wcześniejszy od poznania zmysłowego, gdyż jest on wrodzony. Wrodzoność języka, podobnie jak poznania, oznacza pewnego rodzaj zdolność (facultas) do wyrażenia i artykulacji myśli. Zdolność ta rozwija się wraz z rozwojem struktur świadomości, o których była wcześniej mowa, a także z procesami myślenia. A ponieważ w wykładni augustiańsko-kartezjańskiej, którą przyjął Leibniz, dusza myśli stale, oznacza to, że dusza mówi stale. Jak bowiem pisał Augustyn: „ten, kto myśli, ten - nawet bez dźwięku - mówi w głębi swojego serca"18. Chodzi tu o pierwotny język, którego postacią jest tzw. mowa serca lub język myśli (linqua cordis vel lingua interius).

Czynnikiem, który ostatecznie czyni monadyczny podmiot językowo niezależnym (autarkicznym) od świata zewnętrznego, jest wrodzone nam (łac. insitum), wcześniej wspomniane, lustro naszego umysłu,

16 "Attentio est determinatio animi ad cogitandum aliquid prae aliis quia aliorum non meminit". Textes inédits d'après les manuscrits de la Bibliothèque provinciale de Hanovre, publiés et annotés par Gaston Grua (Paris: Presses Universitaires de France, 1948), 525. Por. Edmund Husserl, Ideen zu einer Reinen Phänomenologie und Phänomenologischen Philosophie. Erstes Buch: Allgemeine Einführung in die reine Phänomenologie (Haag: Martinus Nijhoff, 1950), § 35, 36.

${ }_{17}$ „W każdej chwili jest w nas jednak nieskończona ilość spostrzeżeń bez apercepcji i bez refleksji, tzn. dokonują się zmiany w duszy samej, których nie uświadamiamy sobie [...]". Gottfried Wilhelm Leibniz, NE, Przedmowa, 5.

18 Św. Augustyn, O Trójcy Świętej, przeł. Maria Stokowska (Kraków: Znak, 1996), 480. 
czyli speculum ${ }^{19}$. Pisze o tym Leibniz następujaco w Nowych rozważaniach: ,języki są najlepszym zwierciadłem umysłu ludzkiego i bardziej niż cokolwiek innego ścisła analiza znaczenia słów pozwoliłaby lepiej poznać czynności rozumu" ${ }^{20}$. Język jest projekcją i ekspresją wewnętrznych struktur umysłu. Mowa wewnętrzna (linqua interius), o której pisał św. Augustyn i średniowieczni scholastycy, to wyraz zamkniętego w sobie, „monadycznego" życia umysłu, a język naturalny jest spontaniczną projekcją i zarazem lustrzanym odbiciem tego umysłu. Analiza zaś tego języka daje nam wgląd w naturę naszego umysłu, a w dalszej kolejności w strukturę świata, która jest reprezentowana przez obecne w umyśle pojęcia i twierdzenia (zasady).

\section{Pojęcie osoby. Dwojaka podstawa i forma tożsamości}

Monada w wykładni Leibniza jest bytem osobowym. To struktura, która od początku do końca została wymodelowana na jednostkowym empirycznym ja (,[...] za sprawą duszy lub formy istnieje prawdziwa jedność, odpowiadająca temu, co nazywa się w nas $\left.J a[\ldots]^{\prime \prime}\right)^{21}$. Formą świadomości, która poprzedza rozwój języka i towarzyszy wszelkim aktom poznawczym, jest świadomość tożsamości („A to poznanie towarzyszy zawsze naszym wrażeniom zmysłowym i naszym obecnym spostrzeżeniom, o ile są dość wyraźne [...], i przez to właśnie każdy jest dla siebie tym, co nazywa samym soba" $)^{22}$. Jej językowym wyrazem jest zaimek osoby ego. Bez tej pierwotnej świadomości tożsamości nie tylko nie mogłaby się rozwinąć samoświadomość, która zawsze ma swój jednostkowy podmiot, przez co jest zawsze czyjaśs świadomościa, ale także nie mógłby się wykształcić wspomniany zaimek - ja (ego), ani językowa (gramatyczna) pierwsza osoba liczby pojedynczej.

Leibnizjańska koncepcja tożsamości jest syntezą 1) doktryny o stale myślącej duszy zdolnej do apercepcji i refleksji oraz 2) substancjalnej metafizyki. W podanej przez Leibniza monadycznej interpretacji oba elementy zyskują genetyczna, strukturalną i funkcjonalną jedność. W zależności jednak od tego, który aspekt tej jedności jest rozważany, zyskuje ona inną podstawę. $W$ jednym przypadku jest to tożsamość osobowa (l'identité personelle), oparta na apercepcji i świadomości towarzyszącej

19 Ponieważ racjonalistyczna i zarazem natywistyczna filozofia jest skoncentrowana na umyśle, jako na tak pojętym zwierciadle, stąd nazywana jest ona filozofią spekulatywna.

${ }^{20}$ Leibniz, NR, III, VIII, § 6. Zob. Zob. Halina Święczkowska, Harmonia linguarum - język i jego funkcje w filozofii Leibniza (Białystok: Wydawnictwo Uniwersytet w Białymstoku, 1998).

${ }^{21}$ Leibniz, WWF, 178.

${ }^{22}$ Leibniz, NE, II, XXVI, § 10. 
poszczególnym aktom. $\mathrm{W}$ drugim - tożsamość realna (l'identité reele), oparta na ontycznych strukturach substancjalnych monadycznego podmiotu. Za każdym razem jest to tożsamość osoby, przez którą rozumiał on duchowy podmiot poznania i działania. W Nowych rozważaniach zdefiniował go jako „byt myślący i rozumiejący, zdolny do rozumowania i do refleksji, mogący siebie uważać za tożsamo, za jedną i tą samą rzecz"23. To określenie osoby wskazuje bezpośrednio na - jak go nazywa Leibniz - wymiar moralny (dokładniej: psychologiczny) tożsamości, o którym czytamy:

[...] świadomość (świadomości lub samowiedza) towarzyszy zawsze myśli i to właśnie sprawia, że każdy jest tym, co nazywa się samym sobą. I tym różni się od wszelkiej innej rzeczy myślącej; na tym też polega tożsamość osoby albo to, co sprawia, że byt rozumny jest zawsze ten sam. I jak daleko rozciagać się może ta świadomość na minione już działania i myśli, tak daleko rozciąga się tożsamość tej osoby, a bycie sobą jest obecne tak samo, co wówczas²4.

Tożsamość rozważana w tym aspekcie jest czymś dynamicznym, związanym ze stale dokonywaną percepcją nowych rzeczy i równoczesną z nią świadomością zachodzenia tej percepcji.

Tożsamość realna to stała znajomość (notitia) siebie, należąca do apercepcji. Ta forma tożsamości ma swoją podstawę $\mathrm{w}$ ontyczno-substancjalnej strukturze monadycznego podmiotu, a tożsamość moralna rodzi się w nas dopiero, gdy osoba zaczyna myśleć o sobie, tj. wraz z refleksją. To, co zwykliśmy nazywać znajomością siebie, resp. tożsamościa, dotyczy poziomu aktualnie posiadanej przez nas wiedzy o sobie, uzyskiwanej na bazie refleksji.

To, co najważniejsze i co wynika z powyższego, to fakt, że byt osobowy jest obdarzony świadomościa, która ma różne wymiary i złożoną strukturę. Fundują one różne obszary naszego osobowego bytu, wśród których, np. obok sumienia, jest tożsamość. W myśl przyjmowanego przez Leibniza natywizmu poznanie zmysłowe $\mathrm{w}$ niczym nie poszerza naszego poznania. Dlatego na tym tle poznanie to nie odrywa znaczącej roli, jak w empiryzmie, choć jest konieczne do tego, aby budzić naszą świadomość i wprawiać ją w stan czuwania („nauka z zewnątrz tylko rozbudza to, co jest w nas" NE, I, $1, \S 4$ ). 


\section{Monadologia neurologica}

Empirycznego modelu prezentującego główne elementy monadologicznej koncepcji osoby i świadomości Leibniza dostarczył brytyjsko-amerykański neurolog i psychiatra Oliver Sacks (1933-2015) w pracy pt. Awakenings (1973). W niezwykle błyskotliwy i efektywny sposób zaaplikował zasadnicze elementy Leibnizjańskiej koncepcji monadologicznej świadomości do opisu i wyjaśniania zachowań swoich chorujących na zapalenie mózgowe (Encephalitis lethargica) pacjentów z kliniki Mount Carmel.

\section{Leonard - uśpiona i przebudzona monada}

Z perspektywy naszych rozważań na szczególną uwagę zasługuje opisany przypadek pacjenta o imieniu Leonard, którego postać w znakomity sposób zagrał Robert De Niro w filmie ${ }^{25}$ pod tym samym tytułem co książka Sacksa (Awakenings 1990, reż. Penny Marshall). Pacjent ten był "całkowicie niemy - i zupełnie nieruchomy - mógł poruszać trochę prawą ręką dzięki czemu potrafił ułożyć informację na swojej tablicy z literami" (P. 224). W tym stanie czterdziestosześcioletni Leonard znajdował się od dzieciństwa. Sytuacja zmieniła się diametralnie wiosną 1969 roku, gdy Sacks zastosował w jego przypadku lek o nazwie L-dopa. Wtedy to - na krótki czas - ów pacjent powrócił do normalnego życia, zapisywał $\mathrm{w}$ pamiętniku swoje przeżycia zarówno sprzed tego powrotu, jak i wszystko, co działo się w czasie jego trwania, aż do powrotu do pierwotnego stanu choroby. Swoje spostrzeżenia dotyczące przebiegu choroby Leonarda, jak również jego wypowiedzi spisał we wspomnianej pracy Awakenings Oliver Sacks.

Waga poczynionych przez Sacksa analiz przypadku Leonarda polega na tym, że wyłaniający się z nich obraz przebiegu jego choroby i związanych z nią stanów psychicznych wyraźnie ujawnił cały zestaw tych rysów świadomości i twierdzeń, które tworzą podstawy zarysu monadycznej koncepcji osoby i świadomości, jaki znamy z dzieł Leibniza.

\section{Radykalny indywidualizm monadyczny}

Jednym z najważniejszych elementów filozoficznego światopoglądu Sacksa było to, co dałoby się określić jako zasada radykalnego indywidualizmu.

${ }^{25}$ O filmie tym pisałem wcześniej w artykule „Monadologiczna metafizyka Leibniza na ekranie. Wokół filmu Przebudzenia", Kwartalnik Filmowy 96 (2016): 122-136. 
Jej prefigurację znajdujemy w postaci zasady jednostkowienia, którą młody Leibniz tak zdefiniował w swojej pracy bakalarskiej: „byt określa się całą swoją bytowością" („,omne individuum sua tota entitate individuitur"). Sam Sacks wprost się do niej odwołuje, pisząc o poszczególnych swoich pacjentach:

Choroby mają swój własny charakter, ale kształtują również charakter świata: charakter jest monadyczny albo makrokosmiczny, światy wewnątrz światów, światy, które wyrażają światy. Choroba, człowiek, świat idą razem i nie mogą być rozważane osobno, jako rzeczy same w sobie. Adekwatna koncepcja człowieka (Adama w przykładzie Leibniza) obejmuje wszystko, co mu się przydarza, wszystko, co na niego wpływa, i wszystko, na co on wpływa. Stosowane w niej terminy łączą przypadek z koniecznością, pozwalając na bezustanną możliwość istnienia „alternatywnych Adamów" (P. 244/A. 229).

W powyższym fragmencie zaaplikował on do medycyny zaawansowaną monadologiczną teorię jednostkowego podmiotu oraz ontologię światów możliwych. Przed nim nikt tego nie czynił w obszarze medycyny.

Warto przypomnieć, że w późniejszej fazie aktywności Leibniz, na którego powoływał się Sacks, w wykładni natury indywiduum nawiązywał do koncepcji neoplatońskich (m.in. Mikołaja z Kuzy). Ujmował indywiduum jako tzw. ściągnięcie (łac. contractio), a dokładniej: ściągnięcie zwoju - coś na wzór skoncentrowanego przez soczewkę promienia światła. Do tego modelu zwoju nawiązywał Leibniz ${ }^{26}$ przy okazji tłumaczenia zjawisk rozwoju świadomości, który przebiega według schematu: rozwinięcie - ekspilacja (explicatio) - zwinięcie (complicatio). Schemat ten znalazł zastosowanie w opisach świadomości pacjentów Sacksa od stanu początkowego, tj. otwarcia się na świata i „nasze bycie-tu (da-sein) w świecie" 27 („our being-here »da-sein « in the world" A. 228), poprzez stan ujęty słowami Leonarda: „Zwracam się ciągle ku sobie” (P. 253/A. 241), aż po moment zwinięcia się w sobie jako zamkniętości, którą Leonard wyraził słowami wiersza Rainera Marii Rilkego (A. 205). Analizując przypadki dwóch badanych przez siebie pacjentów, zauważał, że $\mathrm{w}$ ich przeciwnych stanach psychicznych zachodzi ciagłość:

[...] w przypadku Leonarda [...] widzimy w zasadzie eksplozywne, natychmiastowe zmiany od stanów „rozszerzania się" do stanów intensywnego „kurczenia się" [...]. Te dwa obserwowane przez nas stany, które

${ }^{26}$ Zob. Leibniz, WWF, 291, 310.

27 Ten termin to oczywiste nawiązanie do Heideggerowskiego „,in-der-Welt-sein" jako pierwotnego fenomenu bycia ludzkiego podmiotu, Dasein. Zob. Martin Heidegger, Sein und Zeit (Frankfurt a. Main: Vittorio Klostermann, 1977), zwł. §9. 
w różnych sytuacjach były nazywane stanami górnymi i dolnymi, są ze sobą precyzyjnie i formalnie związane. Są różnymi fazami tego samego procesu, czasami jeden przechodzi w drugi; przedstawiają zarówno nam, jak i naszym pacjentom przeciwne bieguny ontologicznego kontinuum (P. 264/A. 256).

Radykalny indywidualizm był nie tylko filozoficznym stanowiskiem Sacksa, ale także stanowił podstawę jego poglądu odnośnie do praktyki lekarskiej. Uważał, że kiedy występują różne reakcje na podawanie tego samego leku pacjentom cierpiącym na tę samą chorobę, należy zindywidualizować podejście do pacjenta, ponieważ „nie możemy zrozumieć natury takich reakcji bez odniesienia do natury każdego pacjenta [...]" (P. 268/A. 260-261). Nie tylko każdy pacjent jest niepowtarzalnym indywiduum $^{28}$, ale także jego choroba: „Indywidualność jest nieodzowną cechą choroby, jak wszystkiego" (P. 259/A. 250).

\section{Język i antykartezjanizm}

Bardzo charakterystyczny jest w filozoficznym poglądach Sacksa jego identyczny z Leibnizjańskim - antykartezjanizm w poglądzie na właściwy obraz człowieka i odpowiedni, tj. adekwatny, język opisu choroby pacjentów. Kartezjanizm sprowadzał ludzkie ciało do mechanizmu, który miałby być opisywany i wyjaśniany adekwatnie w języku matematyki i fizyki. W dzisiejszej terminologii ten pogląd Sacksa można by określić jako anty-fizykalizm. Leibniz, pozostając empirystą („We have no need to go beyond the evidence of our senses" A. 233 $)^{29}$, jednocześnie podkreślał - zgodnie z $\S 8$ Monadologii ${ }^{30}$ - jakościowy, w odróżnieniu od ilościowego, kartezjańskiego, punkt widzenia w odniesieniu do człowieka, zwłaszcza pacjenta. Ponadto postulował zmianę języka opisu z ilościowego (fizykalnego) na bardziej adekwatny: „potrzebujemy metody, języka, który jest adekwatny do problemu" (P. 247/A. 233). Tym poszu-

${ }^{28}$ Ten element $\mathrm{w}$ charakterystyce indywiduum, wielokrotnie podkreślanym przez Leibniza w charakterystyce monady, w terminologii scholastycznej oznaczano terminem incommunicabilitas. Przy jego pomocy w średniowiecznej filozofii definiowano osobę. Por. „Nomine personae significatur incommunicabilitas sive individualitas subsistentis in natura" [red. A. Dondaine], Ed. Leon, t. XXII, 1-3 (Roma: Editori di san Tommaso, 1972) II, q. 9, a. 6, co.

${ }^{29} \mathrm{~W}$ tym punkcie Sacks przyjmuje jawnie sprzeczne stanowisko w stosunku do Leibniza - por. Mon. § 28.

${ }^{30}$ „Monady muszą mieć pewne jakości, w przeciwnym razie nie byłby nawet bytami. Gdyby zaś substancje proste nie różniły się jakościami, nie dałoby się dostrzec żadnej zmiany w rzeczach, albowiem to, co znajduje się w rzeczy złożonej, może pochodzić jedynie z jej składników prostych; będąc bez jakości, jedne nie dawałyby się wyodrębnić od innych, skoro nie ma między nimi różnic ilościowych [...]". Leibniz, WWF, 298. 
kiwanym językiem jest język jakościowych kategorii (słownik), gdyż tylko taki może ująć podstawowe relacje, które określają naturę człowieka i jego związki ze światem: „[...] język, którego potrzebujemy, musi być zarówno szczegółowy, jak i ogólny, by móc opisać nim pacjenta i jego naturę oraz świat i jego naturę" (P. 247/A. 233).

Ponieważ sam język i jego słownik muszą możliwie adekwatnie wyrażać różne wymiary opisywanej, złożonej rzeczywistości pacjenta, musi zostać wypracowany język naturalny ${ }^{31}$. Językiem tym posługiwała się klasyczna metafizyka: „Taki język - jednocześnie osobowy i uniwersalny, konkretny i metaforyczny, prosty i głęboki - to język metafizyki albo język potoczny" (P. 247/A. 233).

Piszącojęzyku fizykalnym, wktórym dokonujesięopisodkrytegoleku (L-dopy), zauważa on:

Statystyki ilościowe zawarte w opublikowanych badaniach L-dopy są w rzeczywistości przykładem rachunku szczęśliwych przypadków Benthama („,największe dobro z największej liczy”) albo rachunku hedonicznego F. Y. Edgewortha. Zwięzłość i użyteczność takiego statystycznego podejścia są oczywiste, ale jego ograniczenia (i okrucieństwa) są zamaskowane i ukryte - trzeba je dopiero wyciągnać na światło dzienne. Podejście użytkowe nie jest tu opisywane za pomocą terminów dotyczących szczegółu i ogółu; jego terminy, z konieczności, ukrywają je. Nie dają nam żadnego wglądu w ogólną organizację zachowania albo w sposoby, w których jest to egzemplifikowane u poszczególnych pacjentów (P. 247/A. 233).

Sacks, przeprowadzając swój dyskurs na temat nieadekwatności zastanego w neurologii języka opisu działania stosowanego przez siebie leku, L-dopy, dzięki któremu jego pacjenci powracali do pełni zdrowia, wychodząc z ciężkiego stanu postencefalicznego, aby niespodziewanie i w sposób niewyjaśnialny wrócić do tego stanu, nawiązuje do tezy Leibniza, że zarówno opis, jak i metoda muszą uwzględniać porządek przyczyn sprawczych, który sytuuje się po stronie cielesnej pacjenta, i porządek przyczyn celowych, którego podłożem jest ludzka podmiotowość. Swoje przeświadczenia $\mathrm{w}$ tym względzie zilustrował on fragmentem z Rozprawy metafizycznej (pkt. 21-22) Leibniza, który brzmi: „Uważam, nawet, że wiele zjawisk natury daje się dowieść w sposób dwojaki: mianowicie dzięki uwzględnieniu przyczyny sprawczej, ponadto po części dzięki uwzględnieniu przyczyny celowej [...]. I jedno, i drugie jest dobre, i jedno, i drugie może być pożyteczne nie tylko dla podziwiania sztuki Wielkiego Rzemieślnika, lecz także do odkrycia rzeczy w medycynie"32.

31 Zob. Mieczysław A. Krąpiec, Język i świat naturalny (Lublin: RW KUL 1985).

${ }^{32}$ Leibniz, WWF, 124. Zob. Sacks, P. 242. 
Omawiany psychiatra przyjął też pogląd Leibniza, zgodnie z którym rozważania metafizyczne mają prymat w stosunku do fizykalnych, gdyż „działanie świata nigdy nie narusza rozważań mechanicznych, mają one jednak sens i stają się w pełni zrozumiałe tylko w świetle rozważań metafizycznych; mechanika świata służy planowi stworzenia" (P. 242/A. 227).

$\mathrm{W}$ niezrozumieniu tego faktu upatrywał on problemów, jakie rodzi materialistyczna i mechanistyczna medycyna, której podstawy stworzył Kartezjusz. Amerykański neurolog, podobnie jak w XVII wieku wielki hanowerczyk, oponuje przeciwko redukcjonizmowi w postaci wspomnianego fizykalizmu:

Głupotą jest próba zredukowania kategorii metafizycznych i materii do zagadnień mechanicznych: światów do układów, szczegółów do kategorii, wrażeń do analiz, rzeczywistości do abstrakcji. To jest obłęd trzech ostatnich wieków, obłęd, przez który wielu z nas przeszło i który kusi wszystkich. Jest to podejście Newtona, Locke'a i Kartezjusza - różnorodnie parafrazowane w medycynie, biologii, polityce, przemyśle itp. - które redukuje ludzi do maszyn, automatów, kukiełek, lalek, czystych tablic, formuł, kodów, układów i odruchów" (P. 243/A. 228).

O radykalizmie stanowiska Sacksa w kwestii wyboru właściwego języka do adekwatnego opisu stanu pacjenta świadczy to, że poszedł dużo dalej niż do krytyki kartezjańskiego języka mechanicyzmu i fizykalizmu. W kwestii postulowanego nowego słownika, tj. adekwatnego języka opisu choroby, wyszedł on nawet poza pozycję Leibniza, który wprawdzie przyjmował język naturalny do metafizyki, ale dopiero po uprzedniej procedurze jego pojęciowej klaryfikacji. „To są kategorie metafizyczne - kategorie, które stosujemy do rzecz nieskończonych. Są one powszechne $\mathrm{w}$ dyskursach potocznych, poetyckich i filozoficznych i są niezbędne w dyskursach metafizycznych, które jednoczą pozostałe" (P. 241/A. 224). Taką wypowiedzią Sacks zbliżył się do stanowiska późnego Heideggera ${ }^{33}$, który odrzucał jakiekolwiek formy klaryfikacji czy definiowania podstawowych pojęć języka naturalnego. Zamiast nich niemiecki filozof koncentrował się na wyrażanym spontanicznie (in actu exercito), całkowicie zrozumiałym - i przez to semantycznie przezroczystym - słowniku języka naturalnego. Sacks zaś swoje stanowisko uzasadniał tym, że odpowiedzi pacjentów na pytania wyrażane $\mathrm{w}$ takim właśnie, jakościowym, naturalnym języku ,[...] są intuicyjnie zrozumiałe i obrazują stan pacjenta. Nie jest przyjęte odpowiadanie na takie

33 Por. Martin Heidegger, Unterwegs zur Sprache (Frankfurt a. Main: Vittorio Klostermann, 1985), 147-204, zwł. 88-190. Notabene w pracy Sacksa mamy idiomatyczne wyrażenie przejęte wprost ze słownika filozofii Heideggera: „,being-here (da-sein) in-the-world" (A. 228) - por. Heideggera: Dasein, in-der Welt-Sein etc. 
metafizyczne pytanie listą wyników pomiarów życiowych, analizy krwi i moczu itp. Tysiące takich danych nie dają odpowiedzi na zasadnicze pytanie" (P. 241/A. 225).

\section{Personalizm}

Zastane przez autora Awakenings podejście naukowe do pacjenta budziło w nim na tyle silny sprzeciw, że stawiało pod znakiem zapytania jego poznawczą wartość i miało znamiona antyhumanizmu (,Jest to podejście, które w szczególności powoduje, że współczesna literatura medyczna jest bezwartościowa, niedająca się przeczytać, nieludzka i nierzeczywista" P. 243/A. 228). Sacks nie tracił z oczu tego, co miało stanowić o istocie człowieczego bytu, a mianowicie tego, że człowiek jest osobą. Czytamy bowiem:

Język współczesnej neurologii, na przykład, nie potrafi wskazać, co się dzieje z pacjentem. Nas nie interesują same objawy, ale os oba i jej zmieniający się stosunek do świata. Ponadto język, którego potrzebujemy, musi być zarówno szczegółowy, jak i ogólny, by móc opisać pacjenta i jego naturę oraz świat i jego naturę. Taki język - równocześnie osobowy i uniwersalny, konkretny i metaforyczny, prosty i głęboki to język metafizyki albo język potoczny. [...] Naszym zadaniem - w kontekście reakcji pacjentów na L-dopę - jest badanie znaczenia tych terminów, aby uniknąć sztucznych definicji i dychotomii, i aby czuć (poza zasięgiem sformułowań) dokładna, istotną naturę każdego (P. 247/A. 233).

Jego formułę: "Coś, co nie jest indywidualne, nie jest żywe”, którą rozwija następująco: „Nasze zdrowie jest na s ze. Nasze choroby są nasze. Nasze reakcje są n a s ze - nie mniej niż nasze umysły lub nasze twarze" ${ }^{\prime 34}$ można potraktować jako parafrazę średniowiecznej formuły "actiones [et passiones] sunt individuorum suppositorum"35, którą zastosował w swojej monadycznej metafizyce Leibniz. Pogląd ten, podkreślający indywidualny wymiar pacjenta i jego choroby, jest jedną z pierwotnych przesłanek metafizycznych w poglądzie Sacksa na naturę człowieka. Inną jest jego - powiązana z metafizycznym indywidualizmem - koncepcja świadomości monadycznej.

${ }^{34}$ Sacks, P. 243/A. 228. Końcówka cytatu nieznacznie zmieniona w stosunku do przekładu, ale wierniejsza oryginałowi tekstu.

35 Por. Leibniz, WWF, 105. 


\section{Przebudzenie i stan patologicznego "Uśpienia" monadycznej refleksji}

Leibniz przyjął od Kartezjusza pogląd, że myślenie jest istotowa tj. konieczna, determinacją - atrybutem ludzkiego bytu. Skoro tak, to następstwem przyjęcia tego poglądu było twierdzenie, że człowiek (jego dusza) myśli stale, $\mathrm{w}$ przeciwnym razie musiałby ulec unicestwieniu. Ponieważ zaś niewątpliwie człowiek znajduje się w różnych stanach: od stanu pełni świadomości na jawie po sen i stany omdlenia, Leibniz przyjął zasadę ciągłości (principium continuationis), głosząca, że zachodzi ciagłość świadomości we wszystkich stanach, w jakich znajduje się dusza. Innymi słowy, nie ma "przerw” w ciągłym trwaniu naszej świadomości, ale jedynie zmienia się jej epistemologiczna charakterystyka, a zwłaszcza jasność i wyraźność spostrzeżeń, poziom samoświadomości itd. Zjawisko ciągłości świadomości zarazem funduje jeden z podstawowych wymiarów tożsamości jej podmiotu. Kiedy więc dusza przechodzi w stan snu czy omdlenia, jej świadomość i tożsamość trwa nadal. To zaś oznacza, że w każdej chwil może - w rezultacie przebudzenia - wrócić do wcześniejszego stanu pełni samoświadomości i tożsamości. Takim czynnikiem stymulującym (fr. exciter) przebudzenie świadomości była m.in. szeroko pojęta percepcja zmysłowa (doświadczenie).

\section{Poięcie przebudzenia}

Wspomnianą Leibniza zasadę ciągłości świadomości in extenso przyjmuje Sacks, gdy krytykuje tzw. topistów ${ }^{36}$, czyli przeciwników podejścia holistycznego w neurologii. Stwierdza on bowiem:

Nikt nie uświadamia sobie różnicy pomiędzy na przykład emocjonalnością a czujnością: można sobie zdawać sprawę tylko z tego, że jest się aktywnym, uważnym, świadomym - i z ogólnego, nieskończonego charakteru własnej uwagi i świadomości. Rozdzielając tę ,,jedność" na izolowane składniki, popełnia się solecyzm epistemologiczny pierwszego rodzaju i nie dostrzega się uczuć własnych pacjentów (P. 252/A. 240).

W Sacksa koncepcji świadomości przebudzenie pojęte jako zamierzony w praktyce medycznej stan świadomości, tj. zdrowia psychicznego, było jedną z najważniejszych kategorii neurologiczno-psychiatrycznej teorii wyjaśniającej przejście jego pacjentów np. ze stanu katatonii do pełni świadomości i zaangażowania w otaczającym ich świecie $(\text { milieu })^{37}$.

36 Ang. topists - od gr. $\tau$ ì $\pi$ os - miejsce.

${ }^{37}$ Zob. Sacks, A. 270, przyp. 142. Cf. tamże, 21. 
W szczególności w przypadku opisów dokonywanych przez Sacksa ważne z punktu widzenia przeprowadzanych analiz są stany przebudzenia u pacjentów chorych na chorobę Parkinsona. Ponadto szczególnie interesujące jest to, że podana przez Sacksa - behawiorysty - wykładnia tego stanu artykułowana jest w kategoriach nie behawioralnej psychologii, która świadomość redukuje do relacji bodziec-reakcja, ale klasycznej epistemologii, która definiuje to zjawisko przy pomocy kategorii relacji jako odniesienia (łac. intentio): „Przebudzenie polega na zmianie świadomości, stosunku do siebie i świata" (P. 252/A. 240).

Ta zamiana relacji to zmiana kierunku intencji świadomości z siebie samego na zewnętrzny świat, czyli przejście od stanu refleksji, jako swoistego pogrążenia się w sobie samym, do naturalnej intencjonalności zorientowanej na świat poza nami. Jest to przejście od refleksji do, jak powiedziałby Heidegger, bycia-w-świecie. W stanie przebudzenia pacjent odczuwa

pełną obecność świata. [...] zwraca się więc do świata, już nie jest pochłonięty chorobą. Zwraca swoją uwagę na świat, kochającą i prostoduszną uwaga, tym bardziej że był on tak długo „odcięty" i „uśpiony”. Świat znowu staje się dla niego cudownie żywy. Wszystko wokół przebudzonego pacjenta wydaje się ciekawe, zdumiewające, zabawne - jak gdyby był znowu dzieckiem albo wyszedł z więzienia. Zakochuje się W rzeczywistości. Jest ponownie zjednoczony ze światem i z samym sobą (P. 253/A. 241).

Z podanych gdzie indziej przez Sacksa opisów wynika, że świadomość przebudzonych pacjentów odznacza się szczególną wyraźnościq percepcji, objawiającą się zdolnością do koncentracji uwagi na poszczególnych obiektach, która wcześniej, tj. w stanie choroby, była rozproszona jak promień światła przepuszczony przez zabrudzoną szybę. W tym stanie pacjent rozumiany jako monada Leibniza "rozwija” się, czyli odsłania przed sobą świat, który stoi naprzeciw niego. Ten „rozwój” oznaczający powrót do kontaktu ze światem jest nazywany „powrotem do siebie, przejrzeniem, "ponownym narodzeniem «, jest nieskończenie dramatycznym i wzruszającym zdarzeniem, szczególnie u pacjenta obdarzonego pełną i bogatą jaźnią, która została wywłaszczona przez chorobę na lata albo dziesięciolecia" (P. 250-251/A. 237). Gdzie indziej o stanie przebudzenia pacjentów pisze on: „Dotknęli znowu fundamentów swojej istoty, zakorzenili się $\mathrm{w}$ realności, wrócili na pierwotny grunt, stanęli na ziemi, w swoim domu, który na czas choroby na tak długo opuścili" (P. 282/A. 275). 


\section{Choroba jako syndrom "pułapki refleksii"}

Na tym tle choroba wszystkich postencefalicznych pacjentów, której przebudzenie ma być przezwyciężeniem, polega na tym, że „cierpią [oni] na deficyt i zaburzenia uwagi: $z$ jednej strony czują się odcięci od świata, z drugiej wtopieni w chorobę" (P. 252/A. 240). Sacks jednoznacznie wiąże stan świadomości tych pacjentów z tym, co nazywa „patologicznym przesunięciem uwagi na samego siebie” (P. 252; „pathological in-turning of attention on itself" A. 240). Jeden z jego pacjentów podał opis tego stanu, który z perspektywy niniejszych rozważań może uchodzić za niezwykle istotny: „Zwracam się ciągle ku sobie. Narzucam się sobie. Sugeruję sobie siebie. Jestem ciągle pochłonięty sobąa"38.

W następstwie tego stanu świadomości następuje swoiste zamknięcie się podmiotu w sobie i izolacja. Przypomina to Leibnizjańską "monadę pozbawioną okien" z $\S 7$ Monadologii. I tu, i tam występuje charakterystyczny element odizolowania od świata, jak również znany $\mathrm{z}$ opisywanego zjawiska samo-pogrążenia się $\mathrm{w}$ sobie. To doprawdy zdumiewające, jak bardzo opis stanu pacjenta cierpiącego na skrajną postać choroby Parkinsona daje się opisać w kategoriach filozofii refleksji. Uwaga pacjenta skierowana jest ku niemu samemu jako ujmującemu siebie w akcie refleksji. Tego rodzaju sytuacja inicjuje to, co niekiedy w filozofii nazywane jest ",pułapką refleksji” ${ }^{39}$. Chodzi o to, że pierwotne ukierunkowanie aktu refleksji na podmiot tego aktu wyznacza początek swoistej "logiki” refleksji, w której natychmiast po pierwotnym akcie refleksji pojawia się następny akt refleksji, który ujmuje ten pierwszy. Innymi słowy, po akcie refleksji, w którym osoba zwraca się ku sobie $\mathrm{w}$ pewnej chwili $t$, pojawia się $\mathrm{w}$ następnej chwili $\left(t^{1}\right)$ inny akt refleksji (wyższe „piętro refleksji” ), który ujmuje tę samą osobę, ale jako wcześniej ujmującą siebie $\mathrm{w}$ tamtym wcześniejszym akcie refleksji $\mathrm{w}$ chwili $t$, a po tym ostatnim akcie refleksji następny akt refleksji, który ujmie ten sam podmiot jako ujęty w poprzednich aktach refleksji i tak dalej. Opisane zjawisko pułapki refleksji wiąże się z tym, że poznanie refleksyjne nigdy nie jest poznaniem adekwatnym, ale aspektywnym względem swego przedmiotu. Oba elementy są pochodną naszej poznawczej przygodności. Ponadto $\mathrm{w}$ przypadku zjawiska pułapki refleksji mamy do czynienia $\mathrm{z}$ regressus ad infinitum. Wiedział o tym Leibniz i zjawisko to opisał ${ }^{40}$.

38 Sacks, P. 253 („,My posture continually yields to itself. My posture continually enforces itself. My posture is continually suggesting itself. I am totally absorbed in an absorption of posture" A. 241).

${ }_{39}$ Zob. Wojciech Chudy, Rozwój filozofowania a "pułapka refleksji”. Filozofia refleksji i próby jej przezwyciężania (Lublin: RW KUL, 1995²).

40 Leibniz, NE, II, I, § 19. 
Ściśle rzecz biorąc, gdy weźmiemy pod uwagę opisy zawarte w pracy Sacksa w wymiarze czysto psychologicznym, tego rodzaju regressus wiedzie nas - na planie koła (łac. circulus) - nie tyle w nieskończoność czy do Bytu nieskończonego, ale donikąd (por. Hegla „zła nieskończoność"). Sacks pisze o tym: „Staczanie się w chorobę, gdy raz się zacznie, może następować samo z siebie przez niezliczone błędne koła, dodatnie sprzężenia zwrotne, reakcje łańcuchowe - pierwsze napięcie powoduje następne, pierwszy upadek jest przyczyną następnego [...]" (P. 270-271/ /A. 263). Na ten refleksyjny wymiar choroby wskazuje też inny fragment omawianej pracy, w którym występuje wspomniany wyżej motyw ruchu na planie koła: „,...] ci pacjenci przeszli przez taki zakres i głębię doświadczenia, która nie jest dana ani wymagana od większości ludzi. Mogłoby się wydawać [...], że wielu z ich zatoczyło pełen krag i wróciło z powrotem tam, gdzie byli, do punktu wyjścia [...]" (P. 281-282/A. 274; podkr. B.P.). Sacks częściowo oponuje przeciw takiej diagnozie (,[...] ale w rzeczywistości nie jest to prawdą" P. 281), którą nazywa „powierzchowną" („by superficial criteria”), gdyż właśnie w tym ruchu po okręgu odkrywa swoisty „zysk”, który wiąże z rozwojem samoświadomości. Chodzi o to, że w jego rezultacie pacjent wie i rozumie więcej. Tego rodzaju zysk $\mathrm{w}$ rozwoju świadomości sprawia, że - wzorem heraklitejskiej rzeki - nigdy nie ma powrotu do tego samego punktu wyjścia. Ściśle rzecz biorąc, Sacks odkrywa pojęty po Heglowsku pozytywny wymiar doświadczenia tego, co jego pacjent Leonard nazwał „pustką” i „nieobecnością” ${ }^{41}$. Pozytywność ta dotyczy świadomości, która dzięki tej pustce się rozwija: „Osiągnęli oni głębię, pełnię, bogactwo ducha, świadomość siebie i natury rzeczy osiągalną tylko przez doświadczenie i cierpienie" (P. 282/A. 274).

Jak się zdaje, sednem opisywanego stanu choroby nie jest sam moment refleksyjnego skierowania uwagi na siebie i nieskończony proces "pogrążania" się w sobie, ale utrata zdolności skierowania jej poza siebie. To właśnie miał na uwadze Sacks, gdy pisał o „patologicznym” wymiarze owego stanu pogrążenia się w sobie. W tym kontekście szczególna cecha leku L-dopa polega na tym, że przywraca on krótkotrwałą zdolność do przekierowania owej uwagi na świat.

${ }^{41} \mathrm{~W}$ pełni pokrywa się to z dialektyczną logiką Hegla, która rozpoczyna się od czystego bytu (das reine Seine), który jest przez niego identyfikowany z nicością: „Czysty byt i czyste Nic są tym samym” (,Das reine Sein und das reine Nicht ist also dasselbe"). Gottfried Wilhelm Friedrich Hegel, Wissenschaft der Logik (Berlin: Akademie Verlag, 1975) (cyt. WL), Bd. I, 67. Oba, tj. byt i nicość, stanowią ontologiczną podstawę dla późniejszego rozwoju refleksji. 


\section{Choroba a teoria światów możliwych}

Zagadka, którą usiłował rozwikłać ów neurolog, polegała na tym, że w przypadku każdego pacjenta cierpiącego na tę samą chorobę efektywność tego samego leku była zupełnie różna i różny był przebieg oraz czas powrotu do zdrowia. W obliczu niemożliwości odnalezienia empirycznego modelu, który wyjaśniłby ten stan rzeczy, posłużył się on metafizycznym $^{42}$ modelem światów możliwych, stworzonym przez Leibniza. Koncepcję niemieckiego filozofa potraktował jako heurystyczny model pozwalający zrozumieć to zjawisko i zarazem znaleźć jego ontologiczne podstawy. Ponieważ, jak pisał autor Monadologii, wszelkie zjawiska mają swoje obiektywne podstawy (phenomena bene fundata), brytyjski lekarz, podobnie jak jego wielki niemiecki poprzednik, chce w oparciu o te fenomeny wydobyć na jaw ich metafizyczne, a potem fizyczne podstawy. Te ostatnie odkrywa, posługując się szczególnie pojętą fenomenologią choroby (będzie o tym mowa), a pierwsze w ramach teorii światów możliwych. W odróżnieniu jednak od Leibniza Sacks teorię światów możliwych rozważa nie w kontekście teistycznej onto-teologii, ale w kontekście ontologii tego, co dość ogólnie nazywa "constitution of Nature" (A. 261). Ta pisana wielką literą Natura została przez niego odróżniona od innych, pisanych małą literą natur: świata, poszczególnych pacjentów i ich reakcji, np. na zastosowanie L-dopy ${ }^{43}$.

Z perspektywy ontologii i historii filozofii takie, jak powiedziono, zdawkowe ukazanie ontologicznej podstawy teorii światów możliwych budzi pewien niedosyt. Tym bardziej że sama koncepcja światów możliwych pełni ważną heurystyczną rolę w podanych przez niego opisach. Historyk filozofii będzie spontanicznie identyfikował wspomnianą tu naturę z bytowościa, entitas, o której pisał Jan Duns Szkot i liczni przedstawiciele jego szkoły po Leibniza i Wolffa ${ }^{44}$, a także z rozważaniami Leibniza o essentia, w których wyróżnił on absolutną pisaną wielką literą

${ }^{42}$ Terminy „metafizyka” $\mathrm{i}$ „,ontologia” i ich przymiotnikowe pochodne używam w znaczeniu przyjętym przez Christina Wolffa, a następnie stosowanym przez fenomenologów: Edmunda Husserla i Romana Ingardena.

43 „Nie możemy zrozumieć natury takich reakcji bez odniesienia do natury każdego pacjenta; ani natury każdego pacjenta bez odniesienia do natury świata. Tak więc doszliśmy do tego (co każdy kiedyś wiedział), że konstytucja Natury, wszystkich natur, jest [...]" (P. 268/A. 260-261).

${ }_{44}$ Zob. L. Honnefelder, Scientia transcendens. Die formale Bestimmung der Seiendheit und Realität in der Metaphysik des Mittelalters und der Neuzeit (Duns Scotus - SuárezWolff-Kant-Peirce) (Hamburg: Felix Meiner Verlag, 1990). Por. Bogusław Paź, Filum cognitionis. Przemiany nowożytnej metafizyki w ontologię od Suareza do Kanta (Warszawa: Wydawnictwo IFiS PAN, 2019). 
Essentia ${ }^{45}$, i z jej poszczególnymi konkretyzacjami w postaci zarówno aktualnie istniejacych, jak i czysto możliwych essentiae. Ta pierwsza istota jest wspólna wszystkich pozostałym.

Do przyjętej teorii światów możliwych Sacks zastosował L-dopę jako czynnik aktualizujący (por. Leibniza: Existificans), który

przenosi czas przeszły i czas możliwy każdego pacjenta, jego czas przeszły i jego czas możliwy, do namacalnej teraźniejszości. Światy przeszłe i światy możliwe przechodzą przed nami jak zjawy, bardzo realne - jednak nie do końca, tak jak bywa z duchami. Aktualność, prawdopodobieństwo i rzeczywistość mieszają się w tym niesamowitym, a jednak pięknym spotkaniu, w różnorodności bytu, który możemy tylko nazwać ekstazą [transport] (P. 268/A. 260).

W tym kontekście przyjął on mocną tezę o ścisłym powiązaniu zjawisk psychicznych (zwłaszcza różnych reakcji na ten sam lek) z tym, co nazwał „odniesieniem do doznań i osobowości, do całkowitej konstytucji każdego pacjenta" (P. 268/A. 260). Uzasadniał to ścisłym ontologicznym powiązaniem owych reakcji z ich indywidualną podstawą (natura) w postaci bytu osoby (A. 260-261), a także twierdzeniem o ścisłym powiązaniu jednostkowego podmiotu ze światem jako całością którego

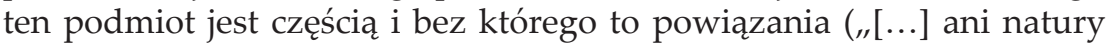
każdego pacjenta bez odniesienia do natury świata" P. 268/A. 261) nie zrozumiemy jego choroby. Jego rozważania na temat światów możliwych w kontekście zdrowienia lub jego braku w przypadku pacjentów leczonych tym samym lekiem są jednak tak mętne, jak „natury"46, o których pisze. Mętne jest także stwierdzenie „problem metafizyczny: kwestią jest to, jak bardzo możemy przywołać jeden świat bez ${ }^{47}$ przywoływania innych, kwestią są także siły i zasoby związane z różnymi światami" (P. 270/A. 262). Tu mamy chyba jakieś niezrozumienie problemu sensu światów możliwych, gdyż albo (1) te światy odwiecznie i niezależnie od siebie $s q$ (bytują), zanim zaistnieje jeden $\mathrm{z}$ nich, tj. ten najlepszy (Leibniz), albo (2) najpierw istnieje aktualnie (egzystuje) jeden ten oto świat i on wyznacza - w ramach współmożliwości (compossibilitas)

45 „Omnes res habent aliquid commune, ipsam scilicet Essentiam seu realitatem. [...] Discrimen realitatis et essentiae. Eadem est in omnibus realitas, non vero eadem in omnibus rebus essentia". Gottfried Wilhelm Leibniz, Sämtliche Schriften und Briefe, Hg. von der Akademie der Wissenschaften (Akademieausgabe), Reihe I-VII (Darmstadt-Leipzig-Berlin: Akademie Verlag, 1923 ff) (cyt. AA) IV A, 26.

${ }^{46} \mathrm{~Np}$. W stwierdzeniu: „We see an actualization or extrusion of natures which were dormant, which were 'sleeping' in posse, and which perhaps might have been best left in posse" A. 262.

${ }^{47} \mathrm{~W}$ polskim przekładzie jest ewidentny błąd; w oryginale mamy: „one world, without summoning others” (podkr. B.P.), co zostało przełożone jako: „świat przez powoływanie innych”, czyli zamiast „bez" widnieje "przez”. 
z nim - pole możliwości (possibilitas realis) różnym innym „światom”. Jeśli więc $L$-dopa aktualizuje możliwości powrotu do zdrowia, to można przyjąć tylko wariant (2), gdyż nie ma ona, tak jak Bóg, mocy aktualizowania czegokolwiek możliwego istniejącego poza czasem i sferą fizyczną. To zaś oznacza, że wspomniane możliwości miały swoją podstawę nie $\mathrm{w}$ jakimś innym świecie, ale w możności (potentia passiva) obecnej $\mathrm{w}$ indywidualnym, aktualnie istniejącym pacjencie, który jest częścią tego oto egzystującego teraz świata.

\section{Fenomenologia choroby. Metoda jej opisu}

Kiedy Sacks przystąpił do opisu różnego rodzaju symptomów nawrotu choroby swoich pacjentów, których na krótki czas przy pomocy L-dopy z niej wyprowadzał, wprost stwierdził, że potrzebujemy koncepcji w adekwatny sposób pozwalającej na adekwatny opis tego zjawiska, obejmujący - jak to sam nazwał - „, all other (monadic) »levels«" (A. 249), a owe stopnie wyrażają gradację bytową (ontologiczne kontinuum) od tego, co najmniej doskonałe, do pełni doskonałości, tj. od najprymitywniejszej monady do doskonałej Monady monad.

Ponieważ to, co cytowany autor nazywa językiem medycznym „symptomami", w języku epistemologii nazywane jest „zjawiskami", więc podane przez niego opisy można by nazwać „fenomenologią" choroby. Heidegger tak definiował fenomenologię: „pozwolić zobaczyć to, co się ukazuje, jak poprzez siebie z siebie się ukazuje"48. Zaprezentowana w książce Sacksa metoda opisu zawiera elementy fenomenologiczno-deiktyczne, które są obecne w przytoczonej definicji. Odsłaniała ona bowiem poszczególne zjawiska z określonej, tj. podmiotowej, perspektywy, a jednocześnie koncentrowała się na ich konkretyzacji poprzez

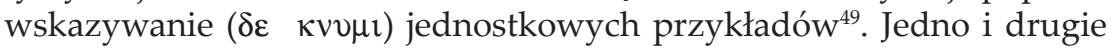
wpisuje się $\mathrm{w}$ to, co Heidegger oznaczał terminem: das Sehenlassen ${ }^{50}$, czyli „umożliwienie” (dosłownie „pozwolenie”) zobaczenia. Z punktu widzenia naszych rozważań najciekawszy jest ten podany przez niego opis, który obejmuje dwie pierwsze i podstawowe, pierwotne fazy rozwoju choroby.

W pierwszej fazie, czytamy, występuje nieokreślona świadomość, "the sense that something is going wrong". Bardzo to przypomina opisy

48 „Das was sich zeigt, so wie es sich von ihm selbst her zeigt, von ihm selbst her sehen lassen". Martin Heidegger, Sein und Zeit (Frankfurt a. Main: Vittorio Klostermann, 1977), 46.

${ }^{49}$ "Wittgenstein once remarked that a book - like the world - could convey its subject-matter by examples, anything further being redundant. My prime intention, in this book, has been to provide examples". Oliver Sacks, A. 232.

${ }^{50}$ Heidegger, Sein und Zeit, 44, 45, 46, 282. 
niepokoju, które znajdujemy w Nowych rozważaniach ${ }^{51}$. W przypadku pacjentów Sacksa przybiera on jednoznacznie negatywny sens, który jest identyczny z tym, o którym pisał Leibniz: „Po niemiecku wahadło zegara nazywa się Unruhe, co znaczy »niepokój« [disquiet]. Można powiedzieć, że tak samo ma rzecz się ma $\mathrm{z}$ naszym ciałem, które nigdy nie jest zaspokojone" (NE, II, XX, § 6). Czytamy mianowicie, że w tym początkowym stanie:

Pacjent nie doświadcza precyzyjnie opracowanej i starannie stabelaryzowanej listy objawów, ale intuicyjnie i bezbłędnie czuje, że coś dolega. Nie jest rozsądne spodziewać się, że będzie on potrafił określić dokładnie, o co chodzi, ponieważ jest to niedające się zdefiniować wrażenie „źledziejstwa", które określa jemu i nam ogólną naturę dolegliwości: wrażenie „złodziejstwa”, którego doświadcza, jest, że tak powiem, jego pierwszym, krótkim przebłyskiem złego świata (P. 259/A. 249).

W przypadku opisywanych pacjentów ów nieokreślony co do przedmiotu niepokój stopniowo przeradzał się w strach, który przez Leibniza był definiowany jako „niepokój duszy, kiedy myśli o przyszłym złu, które może się przydarzyć" ${ }^{\prime \prime 2}$. W pracy Sacksa czytamy zaś: „To poczucie przynosi ze sobą bardzo precyzyjne wskazówki: wszystko, czego się doświadcza, informuje o tym, czego można doświadczyć w przyszłości, mówi o ekspansji i ewolucji już istniejącej cechy [character]" (P. 259/A. 249).

Charakterystyczny jest tu sposób, w jaki Sacks opisuje pierwotne odczucie rosnącej świadomości pewnej postaci zła („the sense of wrongness") u swego pacjenta. Używa on bowiem wyrażenia "glimpse of a wrong world" ${ }^{53}$. Jest to rodzaj intuicji, od której rozpoczyna się proces samoświadomości pacjenta w sferze jego choroby. Jest ona całkiem nieokreślona i niewyraźna, ale posiada bardzo silny stopień poznawczej asercji.

W fazie drugiej najbardziej ogólnymi symptomami nawrotu choroby są niepokój i dysharmonia („unease and discord”). One zarazem „są oznakami i początkiem nawrotu choroby" (P. 259/A. 250). Pochodnym od występującego tu unease terminem uneasiness (jako synonimem dla delight) posługiwał się John Locke, gdy tłumaczył naturę ludzkiego

51 Leibniz, NE II, XX § 6, 8, 10.

52 Tamże, § 10 .

53 "It is not reasonable to expect him to be able to define exactly what is the matter, for it is the indefinable sense of 'wrongness' that indicates to him, and to us, the general nature of his malaise: the sense of wrongness which he experiences is, so to speak, his first glimpse of a wrong world". Sacks, A. 249. 
umysłu $^{54}$. Jednak $w$ jego ujęciu nie miała ona żadnego głębszego sensu. Było to proste, negatywne doznanie jako przeciwieństwo przyjemności i cierpienia („pleasure or pain”; An Essay, II, VII § 2). W ujęciu Leibniza oznaczane tym terminem negatywne zjawiska miały inny sens, dlatego zamiast unease(iness) używał on terminu inquiétude. Kategoria ta miała zasadnicze znaczenie dla objaśnienia podstaw poznania i indywidualnej świadomości. Sacks posługuje się terminem unease w znaczeniu nie Locke'a, ale Leibniza. Wspomniana zaś w cytacie kategoria dysharmonii (discord) jest opozycją względem szeroko pojętej harmonii, czyli jednej z naczelnych kategorii monadologicznej metafizyki Leibniza. Choroba jako taka jest wyrazem dysharmonii ciała i duszy. Jest zakłóceniem porządku w psychofizycznej strukturze pacjenta, co przekłada się na jego stan świadomości, w szczególności na wspomniany stan wewnętrznego niepokoju. Za tym poglądem kryła się intuicja, która sięga tradycji filozofii pitagorejskiej. Jej najważniejszymi kategoriami były: harmonia, porządek i liczba. Doktryna ta miała swój wyraz m.in. w koncepcji muzyki sfer ${ }^{55}$. W myśl jej założeń w zdolności usłyszenia dzięków harmonijnego kosmosu upatrywano wskaźnika wewnętrznego ładu w człowieku.

Stąd więc choroba jako zaburzenie porządku i harmonii w człowieku zyskuje status czegoś na wskroś negatywnego: „choroby są perwersyjnymi, indywidualnymi stworami - światami, nikczemnymi światami. Prostszymi i mocniejszymi niż światy zdrowia" (P. 259/A. 250). Kolejne fazy choroby jako "wyrazy konstytucji Natury" "prezentują się epifanicznie przy wszystkich możliwych okazjach" (A. 261), a ich ontologiczną podstawą źródłem i początkiem jest wspomniana wspólna Natura. Dotyczy to także opisywanych przez Sacksa przypadków schizofrenii, kiedy to „real self only showed itself for a few days, before being decomposed or replaced by swarming 'selflets' sonations of herself" (A. 261-262).

\section{Choroba Encephalitis lethargica a "bezokienność" monad}

Dopiero po zaprezentowaniu głównych założeń interpretacyjnych zastosowanych przez Sacksa i ich genetycznych powiązań z monadologiczną metafizyką Leibniza w pełni możliwe staje się ukazanie główne-

54 John Locke, An Essay concerning Human Understanding, Abridged with an Introduction and Notes by Pauline Phemister (Oxford: Oxford University Press, 2008) (cyt. An Essay), s. 70, 137-139, 151-159, 163-166, 171.

55 Zob. Jamie James, Muzyka sfer. O muzyce, nauce i naturalnym porzadku świata, przeł. Mieczysław Godyń (Kraków: Znak 1996), zwł. 27-85; Oliver Sacks, Muzykofilia. Opowieści o muzyce i mózgu, przeł. Jerzy Łoziński (Poznań: Zysk i S-ka, 2009). 
go zarysu monadycznej świadomości. Paradoksem jest, że monadyczny wymiar naszej, ludzkiej świadomości najwyraźniej ukazuje się nie tyle w stanie zdrowia, ale choroby (Encephalitis lethargica). Jednym z najbardziej charakterystycznych elementów monadyczności naszej świadomości, wręcz jej synonimem, jest zamkniętość i doświadczenie wyalienowania. Obie cechy są następstwem zjawiska, które tu zostało opatrzone mianem „pułapki refleksji”.

\section{Specyfika Encephalitis lethargica jako pułapki refleksji}

Jak już powiedziano, stan wspomnianej choroby wyraża się w cytowanych wcześniej słowach jednego z pacjentów Sacksa: „Zwracam się ciągle ku sobie. Narzucam się sobie. Sugeruję sobie siebie. Jestem stale pochłonięty sobą" (P. 253/A. 241). W języku epistemologii jest to refleksja, jednakże ta jej postać różni się od jej standardowej postaci, która jest udziałem ludzi zdrowych. $W$ ich przypadku refleksja to sytuacja, w której dana osoba zwraca się ku sobie samej w ten sposób, że intencja umysłu (łac. intentio, acies mentis) przekierowuje się od poszczególnych rzeczy ku sobie samej. Tę intencję można przyrównać do prostej, która ulega odchyleniu (flexio) wstecz (re-). W klasycznej psychologii taką prostą (łac. acies mentis) nazywano uwagą. $Z$ tego powodu refleksja definiowana jest jako „zwrot umysłu ku sobie” (Descartes) lub stopniowe „ukierunkowanie uwagi na to, co jest w rzeczy spostrzeżonej”"56. Tak pojęta uwaga - w przypadku osoby zdrowej - podlega koncentracji jak światło skupione w soczewce. Mamy wówczas wyraźna percepcję poszczególnego obiektu refleksji. Natomiast w przypadku pacjentów Sacksa zachodziła wprawdzie refleksja, ale uwaga była całkowicie rozproszona. W rezultacie poznanie okazało się całkowicie niewyraźne jak promień światła przepuszczony przez zabrudzoną szybę. To sprawiało, że pacjenci - jak by to ujął Leibniz - byli „,stale w odrętwieniu" 57 .

W pracy Sacksa znajdujemy szczegółowe, a zarazem dramatyczne opisy procesu utraty zdolności do koncentracji uwagi ${ }^{58}$ Leonarda i próby jej odzyskiwania. Odzyskiwał on ją tylko częściowo i na krótko, jednak

56 Por. „Ciągłe nakierowywanie uwagi na te składniki, które są obecne w rzeczy spostrzeżonej, nazywane jest refleksją" („,Attentions succesiva directio ad ea, quae in re percepta insunt, dicitur Reflexio"). Christian Wolff, Psychologia empirica (Hildesheim: Georg Olms Verlag, 1968), § 257.

57 "Gdyby więc w naszych spostrzeżeniach nie było nic wyodrębnionego i, by tak rzec, wybitnego i bardziej pobudzającego, bylibyśmy w stanie odrętwienia [dans l'étourdissement]". Mon.§ 24 (przekład nieznacznie zmieniony).

58 "All post-encephalitic patients (all patients), in their individual degrees and ways, suffer from defects and distortions of attention: they feel, on the one hand, cutoff or withdrawn from the world, on the other hand immersed, or engrossed, in their illness". Sacks, A. 240. 
nie w czasie obserwacji świata wokół, ale w trakcie refleksji nad soba, tj. gdy pisał autobiografię: „Pisał prawie nieprzerwanie - dwanaście albo piętnaście godzin dziennie. W czasie pisania rzeczywiście potrafił się pozbierać i uwolnić od swoich tików, roztargnień i popędów, które kierowały nim i rozbijały go; kiedy porzucił pisanie, szalone, pikowe palilalie natychmiast potwierdziły znów swoją hegemonię" (A. 213). Ta częściowo odzyskiwana zdolność koncentracji przekładała się na jego sytuację egzystencjalną i ukierunkowanie na kontemplację: „Podczas pisania wróciło jego poczucie siły i wolności, odczuwał także potrzebę absolutnego osamotnienia i koncentracji" (A. 213) W tym jednym, konkretnym przypadku osamotnienie (solitude) było stanem pożądanym, a nawet koniecznym do tego, aby odzyskać kontrolę nad sobą, autonomię i tożsamość.

\section{Zamkniętość i afazja}

We wszystkich pozostałych sytuacjach osamotnienie $\mathrm{u}$ chorego Leonarda było nieszczęściem i przekleństwem, gdyż wzmagało jego poczucie izolacji i zamkniętości. Te dwa elementy doświadczenia zyskały sobie w języku filozoficznym za sprawą Leibniza (Mon. § 7) miano „monadyczności", gdyż wprost nawiązują do formalnych rysów struktury monady jako podstawowej jednostki jego metafizyki. Sacks pisze: „Pod koniec mojego pierwszego z nim spotkania zapytałem: »Jak to jest być w takiej sytuacji, w jakiej pan jest? Czy można ją z czymś porównać? «. Przeliterować następującą odpowiedź: "Zamknięty w klatce. Pozbawiony. Jak Pantera Rilkego"" (P. 225/A. 204-205). Z tego powodu neurolog nazywał swojego pacjenta "czują inteligencja uwięzioną w nieruchomym ciele" (P. 225/A. 204). Doświadczenie zamknięcia i niemożliwości komunikacji z otoczeniem, czyli „bezokienność" Leibniza, było jednym z bardziej poruszających składowych choroby Leonarda i innych pacjentów w Mont Carmel Hospital. Leonard doświadczał zamkniętości w ciele i zarazem tego, że jego energia w nim jest zamknięta: „Kiedy zapytałem go, jak się czuje, zwykle odpowiadał, że pokornie, ale dawał również do zrozumienia, ze czasami miewa poczucie gwałtowności i mocy, która jest zamknięta w jego wnętrzu i której doświadcza tylko w snach. »Nie mam wyjścia. [...]. Jestem uwięziony w ciele. To głupie ciało jest więzieniem z oknami, ale bez drzwi«" (P. 227-228/A. 207). To kolejny charakterystyczny element $\mathrm{w}$ strukturze monad, o którym pisał hanowerczyk: w każdej monadzie obecna jest wchodząca w jej metafizyczną strukturę siła, moc (vis, force) $)^{59}$, która ukierunkowuje, a nawet "pcha” nas do świata. Ta siła to $\mathrm{w}$ ujęciu Leibniza „zasada wewnętrzna sprawiająca

\footnotetext{
${ }^{59}$ Zob. Leibniz, NE, II, XXI, § 1.
} 
zmianę, czyli przejście od jednego spostrzeżenia do drugiego, można [ją] nazwać dążnościa (appétitions) [...]" (Mon. § 15). O tej wewnętrznej sile mówili przebudzeni pacjenci Sacksa, którzy „nie posługują się językiem fizyki, ale językiem ontologicznym lub metafizycznym, który koresponduje $\mathrm{z}$ ich doznaniami. Terminy »ciśnienie« $\mathrm{i}$ »siła « określają organizację choroby i dają pierwsze przesłanki odnośnie do ontologicznej albo "wewnętrznej " przestrzeni u tych pacjentów i u nas wszystkich" (P. 250/A. 237).

Niezależny od cierpiącego chorego i dokonujący się wbrew niemu proces pogrążania się $\mathrm{w}$ sobie powoduje nie tylko efekt izolacji od otoczenia, ale towarzyszą mu jednoczesne blokady w wyrażaniu tych stanów, co wzmacnia wrażenie zamkniętości:

Jego mowa była przerywana nagłymi skojarzeniami myślowymi oraz wielokrotnym powtarzaniem pewnych słów, brzęczeniem i rymowaniem. Pan L. zaczął doświadczać blokowania ruchowego i myślowego bardzo podobnego do tego, które miała Rose M. i Margaret A.; w takich przypadkach nagle wykrzykiwał: „Doktorze Sacks! Doktorze Sacks! Chcę...", ale nie potrafił skończyć tego, co chciał powiedzieć" (P. 234/A. 215).

Taka blokada dotyczy nie tylko mowy, ale także pisania i poruszania $\operatorname{się}^{60}$.

\section{Poezja - język opisu choroby}

W rezultacie pacjent $\mathrm{w}$ trakcie rozwoju choroby stopniowo skazywany był na milczenie, które niejako finalizowało efekt zamknięcia w sobie. Jednak według Leibnizjańskiej zasady, zgodnie z którą dusza myśli stale, to, że pacjent przestaje artykułować słowa, nie oznacza, że przestał myśleć - nawet jeśli znajduje się w stanie letargu. Potwierdzał to Leonard $\mathrm{w}$ swoim pamiętniku pisanym $\mathrm{w}$ trakcie przebudzenia. A ponieważ monada myśli stale, to stale też mówi („omne intelligere in nobis, proprie loquendo, est dicere" $)^{61}$ - chodzi tu o wcześniej wspomnianą Łzw. mowę wewnętrzną lub mowę serca. Dlatego może być mylący zewnętrzny odbiór pacjenta, którego opis podał Sacks:

$60, \ldots[\ldots]$ the same block was also manifested in his letters to me, which were full of violent, exclamatory starts (usually my name, followed by two or three words - in one such letter, impotently repeated twenty-three times) followed by sudden haltings and blocks. And in his walking and movements such blocks were apparent, which suddenly arrested him in mid-motor stream". Sacks, A. 215.

${ }^{61}$ „Wszelkie pojmowanie w nas, właściwe rzecz ujmując, jest mówieniem” [tłum. własne]. S. Thomae de Aquino, Quaestiones disputatae De veritate [ed. A. Dondaine], Ed. Leon, t. XXII, 1-3 (Roma: Editori di san Tommaso, 1972) q. 4, a. 2, ad. 5. 
jego twarz, bez zmarszczek, przypominała twarz dwudziestolatka. Wskazywał skrajną sztywność szyi, tułowia i kończyn oraz dystroficzne zmiany w rękach, które były większe niż dziecka; jego twarz wskazywała maskowatość, a kiedy pojawił się na niej uśmiech, trwał przez wiele minut albo wiele godzin, jak uśmiech Kota z Cheshire; Pan L. był całkowicie niemy, wyłączając chwile nadzwyczajnego podniecenia, kiedy potrafił zawyć lub krzyknąć z dużą siłą. Cierpiał na częste mikronapady - odwiedzenia gałek ocznych połączone z przejściową niezdolnością do wykonania ruchu (P. 225/A. 204).

Wydaje się nam, że u kogoś takiego zatrzymane zostały wszelkie procesy myślowe i poznawcze, a jednak nie. Po stronie pacjenta wygląda to tak, jak opisał to Leonard:

Czasami [...] brakuje mi poczucia impulsu lub aktywnego porwania, jest tylko coś na kształt totalnego uspokojenia, nicości, która w żadnym razie nie jest nieprzyjemna. To jest zelżenie tortury. Z drugiej strony jest rodzajem śmierci. Wtedy czuję, że zostałem wykastrowany przez chorobę i uwolniony od wszystkich tęsknot, które mają inni (P. 225-226/A. 205).

Aby podać jakiś dający się pojąć osobom zdrowym obraz swojego stanu choroby, Leonard wskazał na wiersz Rainera M. Rilkego pt. Pantera, w którym mamy trzy charakterystyczne, monadyczne elementy: po pierwsze klimat bycia zamkniętym: "Czuję, jak gdyby było sztab tysiące / a za sztabami już nie było świata"; po drugie charakterystyczny dla refleksji element refleksyjnego koła: „kręcąc się ciągle w tym najmniejszym kole, / tworzą jakby taniec siły wokół środka"; po trzecie doświadczenie bezsilności: „co więzi ogłuszoną wolę"62. Język poezji najadekwatniej ujmuje realny stan pacjenta, gdyż czyni to tak, jak postulował Sacks: „natychmiast [jest to] ścisłe, intuicyjne, oczywiste, tajemnicze, nieprzeparte i niedefiniowalne" (P. 241/A. 224).

Ten ukazany przez samego Leonarda element jego choroby, jakim jest zamknięcie w sobie i całkowita izolacja od świata, był według niego najstraszniejszy. Jak się wydaje, filozofia ma w swoich zasobach pojęcia i opisy, które mogą wyjaśnić ten stan i pozwolić nam go "zobaczyćc (sehenlassen).

${ }^{62}$ Rainer Maria Rilke, Pantera, w: Rainer Maria Rilke, Poezje, wybrał, przełożył i posłowiem opatrzył Mieczysław Jastrun (Kraków: Wydawnictwo Literackie, 1987), 71. 


\section{Muzyka, czyli w poszukiwaniu pierwszego impulsu}

Jednym z problemów, jaki wyłonił się w niemieckim idealizmie po Leibnizu, był problem tzw. pierwszego impulsu (erster Ansto $\beta)^{63}$, który inicjuje rozwój pierwotnej, prostej świadomości do formy samoświadomości i refleksji. Problem ten pozostaje nierozwiązany na gruncie samej monadologii Leibniza, gdy przyjmiemy dosłownie jego zasadę izolacjonizmu głosząca, że "monady nie mają okien" (Mon. § 7). Chodzi o to, że aby następował rozwój świadomości, musi zadziałać przynajmniej jeden zewnętrzny impuls. Przypomina to ciąg klocków domina, kiedy poruszenie jednego pociąga za sobą ruch kolejnych. W przypadku zamkniętej w sobie, monadycznej świadomości „bez okien” zachodzi taki sam problem zewnętrznego impulsu, który jest konieczny, aby stymulować procesy samoświadomości i refleksji. Innymi słowy, system monad Leibniza nie działa bez takiego pierwszego zewnętrznego impulsu. Takiego stanu doświadczał Leonard, o czym była już mowa wcześniej (P. 225-226/A. 205). W jego przypadku takim zewnętrznym impulsem był dotyk kogoś $\mathrm{z}$ otoczenia, np. pielęgniarki, ale też lek L-dopa. W przypadku innych pacjentów mogło to być cokolwiek innego - często za każdym razem inny czynnik aktywizował poszczególnego pacjenta. Na uwagę zasługuje szczególny przypadek, kiedy to na chorych oddziaływała muzyka (,Godna uwagi jest terapeutyczna moc muzyki, która może ułatwić ruch niemożliwy w innych sytuacjach" P. 278/A. 270). Sacks, który muzyce jako czynnikowi stymulującemu poświęcił osobną monografię ${ }^{64}$, opisał jej wpływ na swoich pacjentów. Rozumienie muzyki przejął wprost od Leibniza, który pisał: „Muzyka jest ukrytym ćwiczeniem arytmetyki duszy nieświadomej tego, że liczy"65. Intuicja zawarta w tej definicji sięga czasów Pitagorasa, który wraz z uczniami ustalił ścisły związek liczby, harmonii i muzyki świata. W tej ostatniej wyraża się ta harmonia. Jego nauka zawierała postulat zachowania jej w duszy jako mikrokosmosie. Sacks znalazł potwierdzenie tej nauki na poziomie struktur mózgu:

${ }^{63}$ W szczególności problem zewnętrznego impulsu umożliwiającego przejście świadomości do poziomu refleksji na świadomość był podejmowany przez Johanna G. Fichtego w jego Wissenschaftlehre ( 1794-1795) (Hamburg: Felix Meiner Verlag, 1984). Rzeczywistość zewnętrzna w tym ujęciu to "nieskończony impuls” (unendlicher Anstoß).

${ }^{64}$ Oliver Sacks, Muzykofilia. Opowieści o muzyce i mózgu, przeł. Jerzy Łoziński (Poznań: Zysk i S-ka, 2009).

${ }_{65} \mathrm{~W}$ oryginale: "Musica est exercitum arithmeticae occultum nescientis se numerare animi". To fragment Listu Leibniza do Goldbacha z 17.04.1712 r., w: G. E. Guhrauer, Gottfried Wilhelm Freiherr von Leibniz. Eine Biographie (Breslau: F. Hirt, 1846), Vol. I, Appendix 66. Cf. Arthur Schopenhauer, „Musica est exercitum metaphysices occultum nescientis se philosophari animi". Zob. Sacks, P. 191-292/A. 283. 
„Leibniz mówił, że muzyka jest tylko nieświadomym liczeniem albo licznikiem, wewnętrznym kroczeniem albo metronomem. Takie wewnętrzne ośrodki nadające tempo i metronomy rzeczywiście istnieją; i są one rzeczywiście ciężko uszkodzone w parkinsonizmie - nasza pacjentka po części to miała na myśli, gdy mówił, że jest »odmuzykalniona «" (P. 292/A. 283-284). Cytowany neurolog rozwija myśl Leibniza w kontekście podanej przez niego definicji muzyki - wskazuje, co nazywa ,jej wewnętrznym ruchem i jej zdolnością do poruszania" (P. 291). Dlatego według niego do rangi istoty muzyki urasta "to, że jest ona jednocześnie ożywiająca i żywa (quickening and quick)" (P. 291-292/ A. 283) i dlatego - za Immanuelem Kantem - pisze on o muzyce jako "Quickening Art" (sztuka ożywiania). W kontekście niniejszych rozważań rzeczone ożywianie za pomocą muzyki to nic innego, jak poszukiwany pierwszy impuls, czynnik wybudzający przebywających w stanie letargu cierpiących jak Leonard monad.

\section{Doświadczenie nicości}

Jak wcześniej powiedziano, stan zamknięcia i izolacji jest spowodowany szczególną formą refleksji, bo nie jest ukierunkowana na określoną treść - obiekt $\mathrm{w}$ nas, np. na element widzianej niegdyś w parku rzeźby $^{66}$. Refleksja ta, jak powiedziano, jest niejako jedynie samym ruchem ku sobie samemu bez odniesienia do świata zewnętrznego, zwłaszcza do jakiegoś konkretnego przedmiotu. Ten ostatni to zawsze jakiś określony byt - indywiduum (das Seiende). To on jest najpierw obiektem percepcji, a dopiero potem refleksji. Jednak w klasycznej metafizyce wyróżnia się też jeszcze inną formę bytu, który jest abstrakcyjny i całkowicie nieokreślony (das Sein $)^{67}$. On nigdy nie jest przedmiotem percepcji, ale jedynie samego myślenia, będąc jego „najsubtelniejszą nicią” (Johnnes Clauberg). Byt $\mathrm{w}$ tym ostatnim znaczeniu w filozofii neoplatońskiej (św. Augustyn) był identyfikowany z obecnością (praesentia), a niekiedy z powodu swojej całkowitej nieokreśloności - z nicością. Przy tak pojętym bycie jako czymś na wskroś nieokreślonym i niedającym się ani wskazać, ani wyrazić zmienia się charakterystyka refleksji, która nas do niego prowadzi. Chyba najodpowiedniejszą jej formułę podał Hegel jako „ruch od nicości do nicości" ${ }^{68}$. W jego ujęciu jest to negatywność w czystej postaci, któ-

${ }^{66}$ Por. Christian Wolff, Psychologia empirica (Hildesheim: Georg Olms Verlag), $1968, \S 257$.

${ }^{67} \mathrm{~W}$ języku scholastyki (począwszy od Jana Dunsa Szkota po Leibniza) byt $\mathrm{w}$ znaczeniu pierwszym był nazywany ens ut participium, $\mathrm{w}$ znaczeniu drugim - ens ut nomen.

${ }^{68}$ "die Bewegung von Nichts zu Nichts". Hegel, WL, Bd. II, 13. Hegel przez tak pojęty ruch definiuje nie tylko refleksję, ale również sam nieokreślony byt, Sein: „Das Sein ist nur als Bewegung des Nichts zu Nichts". Tamże, II, 14. 
ra jest samym ruchem myślenia w pustce pozbawionej intencjonalnego odniesienia do świata. Przez brak tego odniesienia pozbawieni jesteśmy zakotwiczenia w świecie, który budzi nas i przywraca do życia. Wspomnianą negatywność opisał Leonard:

Pan L. za pomocą swoich przenikliwych obrazów, pomysłowych metafor i dzięki swojej wyobraźni poetyckiej próbował określić naturę swego istnienia i doświadczenia. „To jest straszna obecność i straszna nieobecność. Obecność jest mieszaniną udręki, nacisku i presji, jest przy tym wyhamowana, ograniczona i zatrzymana - często nazywam ją »ostroga i uzdą«. Nieobecność jest przerażającą izolacja, chłodem i ścieśnieniem straszniejszą niż ktokolwiek może sobie wyobrazić, doktorze Sacks, dużo straszniejszą niż ktokolwiek, kto nie jest w tym stanie, mógłby sobie wyobrazić - bezdenną ciemnością i nierealnością" (P. 225-226/A. 205).

Leonard tę nieobecność opisał jako: „a sort of total calmless, a nothingness" (A. 205).

Podany opis oprócz aspektu ontologicznego ma też swój wymiar teologiczny, który przez Sacksa został przemilczany, choć on ostatecznie wyjaśnia naturę owej nicości. W chrześcijańskiej teologii mowa jest o wszechobecności (omnipraesentia) Boga w świecie ${ }^{69}$. Jednocześnie piekło jest tam definiowane jako stan, w którym doświadczamy Jego nieobecności. $\mathrm{Z}$ tego względu można powiedzieć, że w podanym wyżej opisie widzimy pewną postać doświadczenia piekła jako nieobecności i braku Bytu absolutnego.

\section{Teodycea w obliczu choroby i cierpienia}

Kiedy mowa o monadach i monadologicznej filozofii Leibniza, nie może zabraknąć kwestii, które pojawiają się w podtytule dzieła Essai de Théodicé, a mianowicie: „sur la bonté de Dieu, la liberté de l'homme et l'origine du mal"70. Pierwszą kwestię Sacks całkowicie pominął, podobnie zresztą jak drugą. Jedynie problem cierpienia został podjęty na stronach Awakenings. Cierpienie bowiem jest jednym z najważniejszych motywów tej książki. Jednak Sacks, inaczej niż Leibniz, nie szuka ostatecznej przyczyny zła i cierpienia. Poprzestaje na fizycznej realności zła i cierpienia,

${ }^{69}$ Tomasz z Akwinu podał trzy podstawowe sposoby istnienia Boga w świecie: per essentiam, potentiam et praesentiam. Jeśli chodzi o tę ostatnią, to czytamy: „Per praesentiam vero suam, dicitur aliquid esse in omnibus quae in prospectu ipsius sunt; sicut omnia quae sunt in aliqua domo, dicuntur esse praesentia alicui, qui tamen non est secundum substantiam suam in qualibet parte domus", Ed. Leon, t. IV (Roma, 1888), Pars I, q. 8, a. 3, ad. 3.

70 Vide: Gottfried Wilhelm Leibniz, Teodycea. O dobroci Boga, wolności człowieka i pochodzeniu zła, przeł. i przypisami opatrzyła Małgorzata Frankiewicz (Warszawa: PWN, 2001). 
w fenomenologii nazywanej faktycznościa, die Fakizität. Nie pyta: dlaczego?, ale koncentruje się na fenomenologicznym wymiarze cierpienia, jakim jest odpowiedź na pytanie: jak? Trzeba przyznać, że opisy te przeprowadza z ogromną wrażliwością i empatią dla pacjentów. Pisał o nich:

Bez woli i winy pacjentów nałożono na ich obowiązek badania otchłani ostatecznych możliwości ludzkiej istoty i cierpienia. Ich ciche poświęcenie nie jest daremne, jeśli dostarcza pomocy albo oświecenia innym, jeśli prowadzą nas do głębszego rozumienia nieszczęścia, opieki i leczenia. To poczucie autentycznego, wspaniałomyślnego, nawet nie dobrowolnego, męczeństwa nie jest nieznane samym pacjentom [...], mówiąc za nich wszystkich (P. 281/A. 273).

Po tych słowach znajdujemy cytat z poruszającej wypowiedzi Leonarda, który po krótkim okresie powrotu do zdrowia na stałe pogrążył się w otchłani choroby: "Jestem żyjącą świeca, zostałem zużyty, żebyś ty mógł się nauczyć. Nowe rzeczy można dojrzeć w świetle mojego cierpienia" (P. 281/A. 273).

Ten pochodzący z końcowej części autobiografii Leonarda opis sprawia, że nie tylko „widzimy” cierpienie tego nieznanego nam pacjenta, ale jesteśmy nim poruszeni. Sacks w podanych prezentacjach pacjentów korzysta $\mathrm{z}$ techniki quasi-fenomenologiczego opisu, ale także z trzech instrumentów (pisteis) greckiej retoryki, którymi są logos, ethos i pathos. Z nich zaś najpełniej wykorzystał ten ostatni i - nade wszystko - pierwszy, czyli rozumowo-filozoficzną argumentację. Nie brak też trzeciego środka nazywanego ethos, czyli argumentacji dotyczącej normatywnego sposobu postępowania wobec pacjentów. W rezultacie udało mu się nie tylko pokazać, ale niezwykle sugestywnie przybliżyć nam cierpienie tych osób. Kiedy mowa o aspekcie teodycealnym opisanego cierpienia, wydaje się, że podane przez niego wyjaśnienia bliższe są ujęciom nie filozofii Leibniza, ale Hegla. W jego książce nie znajdujemy ani odpowiedzi na pytanie, czy jesteśmy wolni, ani nie dowiadujemy się, skąd bierze się zło powodujące cierpienie. Zamiast tego otrzymujemy postulat przyjęcia określonej postawy w obliczu tego cierpienia w postaci uważnej obserwacji i współczucia. W tej wizji teodycei nie ma zbawienia w żadnym tego słowa znaczeniu. Zamiast niego Sacks przyjmuje jako konieczność to, co Hegel nazywał Aufhebung (zniesienie) ${ }^{71}$. Chodziło o włączenie siebie $\mathrm{w}$ nieskończony proces przezwyciężania kolejnych form cierpienia, które skutkuje nabywaniem wyższego stopnia samoświadomości, czyli przebudzenia (A. 274).

${ }^{71}$ Kluczowy w filozofii Hegla termin Aufhebung ma trzy znaczenia: negare - negacja, conservare - zachowanie i elevare - wzniesienie się na wyższy poziom świadomości. 


\section{Uwagi kryłyczne i zakończenie}

Monadologiczna metafizyka, psychologia i epistemologia Leibniza są systemem. To znaczy, że każdy element ma swoje określone, uzasadnione miejsce na tle całości. W rezultacie użycie jednego pojęcia metafizyki Leibniza pociąga za sobą określone konsekwencje dla sądów i opisów, w których one występują. W szczególności dotyczy to takich pojęć, jak monada i świat możliwy. Oba mają określony, ścisły sens, których systematyczny wykład został zaprezentowany w Zasadach filozofii, czyli Monadologii (1714). Oczywiście można posługiwać się zastanym terminem i nadać mu inne znaczenie, lecz znaczenie to trzeba wyraźnie zdefiniować. Sacks posługuje się terminami metafizyki Leibniza, ale nie wyciąga pełnych, ontologicznych konsekwencji, które one presuponuja, ani nie podaje ich własnych definicji. Pojęcie monady presuponuje m.in. metafizyczny związek wszystkich bytów jednostkowych oraz ich gradację od najmniej doskonałego do tego, który posiada pełnię doskonałości Boga jako "monady monad”. On jest ostateczną i dostateczną przyczyną zarówno egzystencji, jak i tego, co jest bytem czysto możliwym (Mon. §36-46). W tym Bycie jest jedność przyczynowości sprawczej i celowej, którą postulował i której szukał Sacks (A. 227, 247, 284). Jednocześnie ten Byt jest ostateczną i dostateczną przyczyną naszego poznania zarówno w sensie jego treści, jak i przebiegu. Bóg jako metafizyczna Ratio swoją obecnością przenika całą naturę („,Ratio est in Natura...” GP VII, 289), którą w trakcie choroby w aktach refleksji poznają pacjenci opisani przez Sacksa. Poznanie zaś racji natury dostarcza odpowiedzi nie tylko o najwyższą przyczynę, ale także o to, jaka jest relacja pomiędzy bytem i nicością. Leibniz w pojęciu monady odkrywał jej pierwotne ukierunkowanie na Byt nieskończony ${ }^{72}$, Boga, który był nie tylko przyczyną istnienia świata, ale i jego ostatecznym celem. Sacks zaś w podanych opisach całkowicie to odniesienie pominął, poprzestając na poziomie tego, co David Hume nazywał matter of facts ${ }^{73}$. Zgadza sie to $z$ deklarowanym przez Sacksa empiryzmem: "We have no need to go beyond the evidence of our senses" (A. 233), jednak trzymajac się tego - uczy nas o tym Hume - nie ma on prawa do żadnego ze swych twierdzeń, np. o światach możliwych. Po pierwsze dlatego, że zmysty nigdy nie uprawniaja nas do mówienia o czymkolwiek poza tym, co

${ }^{72}$ Ten rodzaj ukierunkowania bytu przygodnego na byt absolutny w średniowiecznej scholastyce nosił miano intencjonalności. Było to jedno z podstawowych znaczeń tego terminu, obok odniesienia umysłu do czegoś na zewnątrz niego (in aliquid tendere). Zob. A. M. Heimler, Die Bedeutung der "Intentionalität" im Bereich des Seins nach Thomas von Aquin (Würzburg: Konrad Trilsch, 1962).

73 Zob. David Hume, An Enquiry concerning Human Understanding, ed. with an Introduction and Notes by Peter Millcan (New York: Oxford University Press, 2007), $28-34$. 
aktualnie istnieje i co aktualnie spostrzegamy. Po drugie światy możliwe jako takie nie sa ani przedmiotami zmysłów, ani nie maja w nich swojej genezy, która maja jedynie w rozumie. Po trzecie te światy sa możliwe jako entia possibilia jedynie na mocy Bytu koniecznego, który był przez Leibniza nazywany Existificans (GP VII, 289). Trzymając się empiryzmu, a zwłaszcza deklarowanego behawioryzmu, Sacks nie miał żadnych epistemologicznych i ontologicznych podstaw do swoich licznych twierdzeń m.in. o zachowaniu ciągłości tożsamości pacjentów lub ciągłości myślenia, gdyż obalił je na gruncie empiryzmu John Locke. W szczególności behawioryzm, który redukuje świadomość do relacji bodziec-reakcja, nie ma nic do powiedzenia ani na temat klasycznej refleksji, o której była mowa wcześniej, ani na temat funkcjonowania świadomości i percepcji świata u tych pacjentów, którzy jak monady bez okien trwają w stanie całkowitego letargu lub katatonii ze stuporem. Choć wielokrotnie Sacks stawia filozoficzne pytanie dlaczego ${ }^{74}$, to deklarowane przez niego założenia empirystyczne sprawiaja że pytania te muszą pozostać bez odpowiedzi.

Oliver Sacks w zaprezentowanych w swojej książce opisach i rozważaniach poszedł dużo dalej niż inni naukowcy z jego dyscypliny, tj. neurologii i psychiatrii. Przedstawiona przez niego wykładnia monadycznej koncepcji świadomości, pomimo czynionych przez niego deklaracji, wykracza poza empiryzm i behawioryzm, sięgając do metafizyczno-monadologicznych założeń Leibniza. W ten sposób, być może nie do końca świadomie, ale realnie i konsekwentnie, Sacks prezentuje - np. przy okazji krytyki języka fizykalizmu w psychiatrii - pogląd Leibniza, zgodnie z którym sama fizyka (medycyna) nie tłumaczy swoich zasad przy wyjaśnianiu zjawisk świata, ale czyni to dopiero metafizyka, wykraczająca poza zjawiska do ich ukrytych podstaw. Tak czyni też Sacks i jest to jego prawdziwa felix cupa, gdyż dzięki temu analizowana książka zyskuje na filozoficzno-antropologicznej głębi. Autor osiągnął ją za sprawą swojej wiedzy naukowej, doświadczenia, ogromnej humanistycznej erudycji i empatii. Dzięki znakomitym opisom swoich pacjentów i ich cierpienia pokazał nam, czytelnikom, dużo więcej niż inni przed nim. Zarówno książka Awakenings, jak i jej filmowa ekranizacja przybliżają nam nieznany świat osób chorych, którzy żyją wokół nas.

${ }^{74} \mathrm{~Np}$. „Thus, we are brought back once more to our torturing 'Why?' Why did so many of our patients, after doing so well at first, spoil, 'go bad,' move into all sorts of trouble?". Sacks, A. 262. 


\section{Bibliografia}

Arnauld Antoine. 1990. On True and False Ideas. New Objections to Descartes Replies. Translated, with Introduction by Ellmar J. Kramer. New York: The Edwin Mellen Press.

Arnauld Antoine. 2001. De Vraise et des fausses idées. Edition, presentation et notes par Daniel Moreau. Paris: Libraire Philosophique J. Vrin.

Aristoteles. 1995. Über die Seele. Griechisch-Deutsch. Mit Einletung. Übersetzung und Kommentar von Horst Seidl. Hamburg: Meiner Verlag.

Augustyn. 1996. O Trójcy Świętej, przeł. Maria Stokowska. Kraków: Znak.

Chudy Wojciech. 1995. Rozwój filozofowania a "pułapka refleksji”. Filozofia refleksji i próby jej przezwyciężania. Lublin: RW KUL.

Descartes Rene. 1897-1913. Oeuvres de Descartes. Publiées par Charles Adam et Paul Tannery. Paris: Leopold Carft.

Fichte Johann Gottlieb. 1984. Wissenschaftslehre. Hamburg: Felix Meiner Verlag.

Gottlieb Wilhelm Leibniz. 1969. Wyznanie wiary filozofa. Rozprawa Metafizyczna. Monadologia. Zasady natury i łaski oraz inne pisma filozoficzne, przeł. Stanisław Cichowicz, Juliusz Domański, Henryk Krzeczkowski, Henryk Moese, oprac. Stanisław Cichowicz. Warszawa: PWN.

Guhrauer G. E. 1846. Gottfried Wilhelm Freiherr von Leibniz. Eine Biographie. Vol. 1. Breslau: F. Hirt.

Hegel Gottfried Wilhelm Friedrich. 1975. Wissenschaft der Logik. Bd. I-II. Berlin: Akademie Verlag.

Heidegger Martin. 1977. Sein und Zeit. Frankfurt a. Main: Vittorio Klostermann.

Heidegger Martin. 1985. Unterwegs zur Sprache. Frankfurt a. Main: Vittorio Klostermann.

Heidegger Martin. 2003. Holzwege. Frankfurt a. Main: Vittorio Klostermann.

Heimler Adolf M. 1962. Die Bedeutung der Intentionalität im Bereich des Seins nach Thomas von Aquin. Versuch einer Synthese. Würzburg: Verlag Triltsch Ochsenfurt.

Honnefelder Ludger. 1990. Scientia transcendens. Die formale Bestimmung der Seiendheit und Realität in der Metaphysik des Mittelalters und der Neuzeit (Duns Scotus - Suárez - Wolff - Kant - Peirce). Hamburg: Felix Meiner Verlag.

Hume David. 2007. An Enquiry concerning Human Understanding, ed. with an Introduction and Notes by Peter Millcan. New York: Oxford University Press.

Husserl Edmund. 1950. Ideen zu einer Reinen Phänomenologie und Phänomenologischen Philosophie. Erstes Buch: Allgemeine Einführung in die reine Phänomenologie. Haag: Martinus Nijhoff.

James Jamie. 1996. Muzyka sfer. O muzyce, nauce i naturalnym porząku świata, przeł. Mieczysław Godyń, Kraków: Znak.

Krąpiec Mieczysław Albert. 1985. Język i świat naturalny. Lublin: RW KUL. 
Leibniz Gottfried Wilhelm. 1875-1890. Die philosophischen Schriften von Gottfried Wilhelm Leibniz. red. C. I. Gerhardt. Hildesheim: Georg Olms Verlag (reprint 1978).

Leibniz Gottfried Wilhelm. 1923 ff. Sämtliche Schriften und Briefe, hg. von der Akademie der Wissenschaften (Akademieausgabe). Reihe I-VII. Darmstadt-Leipzig-Berlin: Akademie Verlag.

Leibniz Gottfried Wilhelm. 1948. Textes inédits d'après les manuscrits de la Bibliothèque provinciale de Hanovre. Publiés et annotés par Gaston Grua. Paris: Presses universitaires de France.

Leibniz Gottfried Wilhelm. 2001. Nowe rozważania dotyczace natury umysłu ludzkiego, przeł. Izydora Dąmbska. Kęty: Antyk.

Leibniz Gottfried Wilhelm. 2001. Teodycea. O dobroci Boga, wolności człowieka i pochodzeniu zła, przeł. i przypisami opatrzyła Małgorzata Frankiewicz. Warszawa: PWN.

Leibniz Gottfried Wilhelm. 1999. Pisma z metafizyki natury, red. S. Blandzi. Toruń: Wydawnictwo Rolewski.

Locke John. 2008. An Essay concerning Human Understanding, abridged with an Introduction and Notes by Pauline Phemister. Oxford: Oxford University Press.

Marras Cristina. 2008. The Role of Metaphor in Leibniz's Epistemology. W: Leibniz: What Kind of Rationalist?, red. Marcelo Dascal, 199-212. New York: Springer Verlag.

Paź Bogusław. 2016. „Cogito i intencjonalność. Realistyczny wymiar epistemologii i monadologicznej metafizyki Leibniza". Przegląd Filozoficzny. Nowa Seria 25, 4: 69-92.

Paź Bogusław. 2016. „Cogito und Intentionalität. Leibniz’ Umdeutung des Grundprinzips von Descartes”. W: Für unser Glück oder das Glück anderer, red. Wenchao Li i in., 101-111. Band IV. Vorträge des X. Internationalen Leibniz-Kongresses Hannover, 18.-23. Juli 2016. Hildesheim: Olms Verlag.

Paź Bogusław. 2019. Filum cognitionis. Przemiany nowożytnej metafizyki $w$ ontologie od Suareza do Kanta. Warszawa: Wydawnictwo IFiS PAN.

Paź Bogusław. 2016. „Monadologiczna metafizyka Leibniza na ekranie. Wokół filmu Przebudzenia". Kwartalnik Filmowy 96: 122-136.

Rilke Rainer Maria. 1987. Poezje, wybrał, przełożył i posłowiem opatrzył Mieczysław Jastrun. Kraków: Wydawnictwo Literackie.

Sacks Oliver. 2009. Muzykofilia. Opowieści o muzyce i mózgu, przeł. Jerzy Łoziński. Poznań: Wydawnictwo Zysk i S-ka.

Sacks Oliver. 1999. Awakenings. New York: Vintage Books.

Sacks Oliver. 2009. Muzykofilia. Opowieści o muzyce i mózgu, przeł. Jerzy Łoziński. Poznań: Wydawnictwo Zysk i S-ka.

Sacks Oliver. 2011². Przebudzenia, przeł. Piotr Jaśkowski. Warszawa: Wydawnictwo Zysk i S-ka.

Sannctae Thomae de Aquino. 1972. Quaestiones disputatae De veritate [ed. A. Dondaine]. Ed. Leon. T. XXII, 1-3. Roma: Editori di san Tommaso. 
Sanctae Thomae de Aquino. Corpus Thomisticum, Opera omnia, wydanie internetowe https://www.corpusthomisticum.org/iopera.html

Święczkowska Halina. 1998. Harmonia linguarum - język i jego funkcje w filozo-

fii Leibniza. Białystok: Wydawnictwo Uniwersytet w Białymstoku.

Wolff Christian. 1968. Psychologia empirica. Hildesheim: Georg Olm Verlag.

\section{Streszczenie}

Główny przedmiot niniejszego tekstu stanowi prezentacja Olivera Sacksa, neurologa i psychiatry, wykładni monadologicznej teorii świadomości i osobowego podmiotu, która ma swoje źródło w filozofii Leibniza. Celem pracy jest wykazanie, że w neurologii i psychiatrii znajdujemy zjawiska, które ilustrują i potwierdzają główne twierdzenia Monadologii. W szczególności chodzi o wykazanie, że Sacks w swoich neurologiczno-psychiatrycznych opisach stanów pacjentów przyjął monadyczną koncepcję świadomości. Z filozoficznego punktu widzenia przedsięwzięcie brytyjskiego neurologa sprawiło, że pozornie abstrakcyjna i nienaoczna monadologiczna teoria niemieckiego myśliciela zyskała swój empiryczny model, który wyraża główne jej tezy, a także ukazany został nowy sens i wartość monadologii jako głębokiej, metafizycznej podstawy rozumienia człowieka.

Słowa kluczowe: monada, świadomość, osoba, tożsamość realna i moralna, język naturalny i sztuczny, intencjonalność, refleksja, izolacjonizm, światy możliwe, przebudzenie, choroba, cierpienie

\section{Monadologia neurologica. An Interpretation of the Monadological Theory of Consciousness according to Oliver Sacks}

\section{Summary}

In the paper, I analyze a book by Oliver Sacks, a British-American psychiatrist and neurologist. The main aims of this paper are: first, to show real connections between Oliver Sacks's conception of the person and Leibniz's theory of monadological consciousness; second, to prove that the main principles of Leibniz's philosophy (especially anthropology) best enable us to explain the essential elements of our experience, such as identity and memory.

Keywords: monad, consciousness, person, real and moral identity, ordinary and artificial language, intentionality, reflection, isolationism, possible worlds, awakening, disease, suffering 